\title{
A Jurassic (Bathonian-Callovian) Daghanirhynchia brachiopod fauna from Jordan
}

\author{
H.R. FELDMAN ${ }^{|1,2|}$ M. SCHEMM-GREGORY ${ }^{\left|3,4,{ }^{*}\right|}$ F. AHMAD ${ }^{|5|}$ M.A. WILSON ${ }^{|6|}$ \\ | $\left.1\right|_{\text {American Museum of Natural History, Division of Paleontology (Invertebrates) }}$ \\ New York, NY 10024, USA. E-mail: feldspar4@optonline.net \\ ${ }^{1} 2$ | Lander College for Women, the Anna Ruth and Mark Hasten School, a Division of Touro College \\ New York, NY 10023, USA \\ | 3 | Centro de Geociências da Universidade de Coimbra \\ Largo Marquês de Pombal, 3000-272 Coimbra, Portugal (*Deceased) \\ | 4 | Museu Geológico, Laboratório Nacional de Energia e Geologia (LNEG) \\ Rua Academia das Ciências, 19, 1200-003 Lisboa, Portugal \\ ${ }^{15}$ | Faculty of Natural Resources and Environment, Department of Earth and Environmental Sciences, The Hashemite University \\ P.O. Box 150459, 13115 Zarqa, Jordan. E-mail: fayezahmad3@hotmail.com \\ ${ }^{|6|}$ Department of Geology, The College of Wooster \\ 944 College Mall, Wooster, OH 44691, USA. E-mail: mwilson@wooster.edu
}

A Jurassic (Bathonian-Callovian) brachiopod fauna from Jordan consists of seven rhynchonellid species all belonging to the genus Daghanirhynchia of which two are new: Daghanirhynchia rawyaensis and D. jordanica. Emended diagnoses are given for Daghanirhynchia daghaniensis and D. macfadyeni. Additional taxa described include Daghanirhynchia angulocostata, D. susanae and D. triangulata. Threedimensional reconstructions illustrate the internal morphology of the articulated shells for the first time in this genus. The material studied herein was collected from Wadi Zarqa in northwestern Jordan, almost due north of the Dead Sea, and to the east of the Rift Valley. Most species seem to be geographically restricted within the Jurassic Ethiopian Province, however specimens from Somalia and Ethiopia are larger in size than in other parts of the Province and shell size increases in stratigraphically younger specimens. The occurrence of Daghanirhynchia in India is the only appearance of the genus outside the Ethiopian Province. 


\section{INTRODUCTION}

According to Kiessling et al. (2011) the Jurassic Ethiopian Province includes Tunisia, the Levant, Arabia and much of East Africa, but excludes Tanzania and India. They consider that the special status of India and Tanzania is possibly due to latitudinal gradients in faunal composition. In this paper we believe that the Ethiopian Province consists of today's Arabian Peninsula, Jordan, the Sinai Peninsula and other neighboring basins, the Horn of Africa, parts of the eastern Mediterranean coast, and northeastern Africa. During the Middle Jurassic it was part of the southern Tethys with a characteristic faunal content. Strata of the Ethiopian Province were studied intensely during petroleum exploration after the First World War; however, primary attention was paid to structural geology and sedimentology. Italian and British geologists made large fossil collections that were described piecemeal by paleontologists (e.g. Weir, 1925, 1929; Hudson, 1958; Jaboli, 1959; Ficcarelli, 1968). Strata of the Ethiopian Province were studied intensely during petroleum exploration after the First World War; however, primary attention was paid to structural geology and sedimentology. Italian and British geologists made large fossil collections that were described piecemeal by paleontologists (e.g. Weir 1925, 1929; Hudson, 1958; Jaboli, 1959; Ficcarelli, 1968). Special attention was paid to the ammonite and foraminiferal faunas because of their stratigraphical value. Referring to the brachiopod faunal assemblages, Weir (1925, 1929) and Muir-Wood $(1935,1936)$ described the brachiopod fauna from Somalia; Weir (1929) from Kenya, Cooper $(1983,1989)$ from Saudi Arabia, and Feldman (1986, 1987), Feldman et al. (1991, 2012a), and Hegab (1989, 1992) from Sinai; Feldman et al. (2001) and Krawczynski and Wilson (2011) from Israel, and Feldman et al. (2012b) from Jordan. A more detailed stratigraphical summary of the Jurassic strata in Somalia (formerly British Somaliland) can be found in Weir (1929) and Muir-Wood (1935). Cooper (1989) described brachiopods from Saudi Arabia that were collected from $1125.6 \mathrm{~m}$ of Jurassic strata. These strata are comprised of seven formations, for a more detailed description of these formations see Cooper (1989) and Sharief (et al., 1991). Overall correlation of the faunas among these regions on a larger scale is, with few exceptions, still lacking. This paper is one of a series dealing with fossil finds from Jordan and their correlation with various regions within the Ethiopian Province.

The genus Daghanirhynchia was first established by Muir-Wood(1935). However, its first species were described by Weir (1925) and subsequently Cooper (1989) described additional species. Cooper (1989) and Shi and Grant (1993) discussed the inclusion of taxa assigned to other genera into Daghanirhynchia. In a preliminary work, Feldman et al. (2012b, figs. 1-3) identified a new species in the Arda section of Jordan. Two new species of Daghanirhynchia are described herein and the paleobiogeographical relationship between the Daghanirhynchia faunas from the Ethiopian Province is noted. The genus occurs in the Sinai Peninsula at Gebel Engabashi (Feldman, et al., 2012a) and Saudi Arabia (Cooper, 1989) however this distribution is a bit puzzling since it is apparently missing from correlative strata in the Negev. This paper presents new data that will add to our knowledge of the distribution of the genus within the Jurassic Ethiopian Province, enhance the genus as a biostratigraphical tool and increase our knowledge of the genus within the Tethyan Faunal Realm as a whole, except for the comparison with specimens from Asia which were omitted due to lack of material.

\section{GEOLOGICAL SETTING}

The material studied herein include two stratigraphic sections, the Arda section and the Tel el Dhahab section, both from Wadi Zarqa (Figs. 1; 2) in northwestern Jordan almost due north of the Dead Sea. Wadi Zarqa was first recognized by Wetzstein (1859) and further discussed by Libbey and Hoskins (1905). The base of the Jurassic in northwestern Jordan lies on Triassic siliciclastic sediments (Bender, 1974). The Jurassic in northwestern Jordan is subdivided into seven formations: Hihi, Nimr, Silal, Dhahab, Ramla, Hamam, and Mughanniyya (Khalil and Muneizel, 1992). Brachiopod-bearing levels are found in the Hamam Formation (Bathonian) and Mughanniyya Formation (Callovian) (Fig. 3). The ages of the formations under study are based mainly on bivalves, gastropods and corals since ammonites are relatively scarce in the region (Ahmad, 2002).

The mixed carbonate and siliciclastic Hamam Formation was defined by Khalil and Muneizel (1992) from its type area along Wadi Hamam. It consists of friable sandstones, marls, and clayey silts. Its base is marked by the first appearance of fossiliferous limestone beds, whereas the top is marked by to the overlying Mughhanniyya Formation.

The Mughanniyya Formation is composed of alternating claystones, siltstones, and marly limestone beds with minor dolomite, dolomitic limestone, and coquinas; it represents the upper part of the Jurassic sequence in Jordan cropping out consistently below the overlying Kurnub Sandstone Group.

\section{STRATIGRAPHY AND CORRELATION}

The genus Daghanirhynchia is easy to recognize due to its external morphology and rib structure. It is subtriangular to subpentagonal, subglobose, dorsibiconvex, 
and often with large and curved ventral beak. The shell is uniplicate with a distinct dorsal fold. The costae are coarse and angular and do not bifurcate. There are fine radial striae on the slopes of the costae. Its taxa are very useful index fossils for Middle Jurassic strata from the Ethiopian Province; however, most species seem to be geographically restricted. In general, it can be said that specimens from Somalia and Ethiopia are larger in size than in other parts of the Ethiopian Province and shell size increases in stratigraphically younger specimens. Figure 4 shows an overview of the stratigraphical and geographical distribution of Daghanirhynchia species in the Ethiopian Province. Our data are taken from Weir $(1925,1929)$, MuirWood (1935), Hudson (1958), Jaboli (1959), Dubar (1967), Cooper (1989), Shi and Grant (1993), Howarth and Morris (1998), Ahmad (1998, 2000, 2002, 2003), Feldman et al. (2001, 2012b), the PBDB (Paleobiology Database; http:// www.paleodb.org), and our own observations. According to Kiessling et al. (2011), India, Tanzania, and China are not included in the Ethiopian Province. However, it must be noted that Muir-Wood (1937) reported Daghanirhynchia from India. We believe in the accuracy of her assignment since she had erected the genus. At present, the occurrence of Daghanirhynchia in India is the only appearance of the genus outside the Ethiopian Province. During the Jurassic India was still attached to Africa (Gondwana) and was part of the Ethiopian Province; it began drifting toward Asia only in the Cretaceous.

\section{MATERIAL AND METHODS}

All 213 specimens studied are preserved as articulated shells. To study the internal morphology we used serial sections and computer tomographical (CT) scans of nine specimens. The latter was only suitable for the type species,

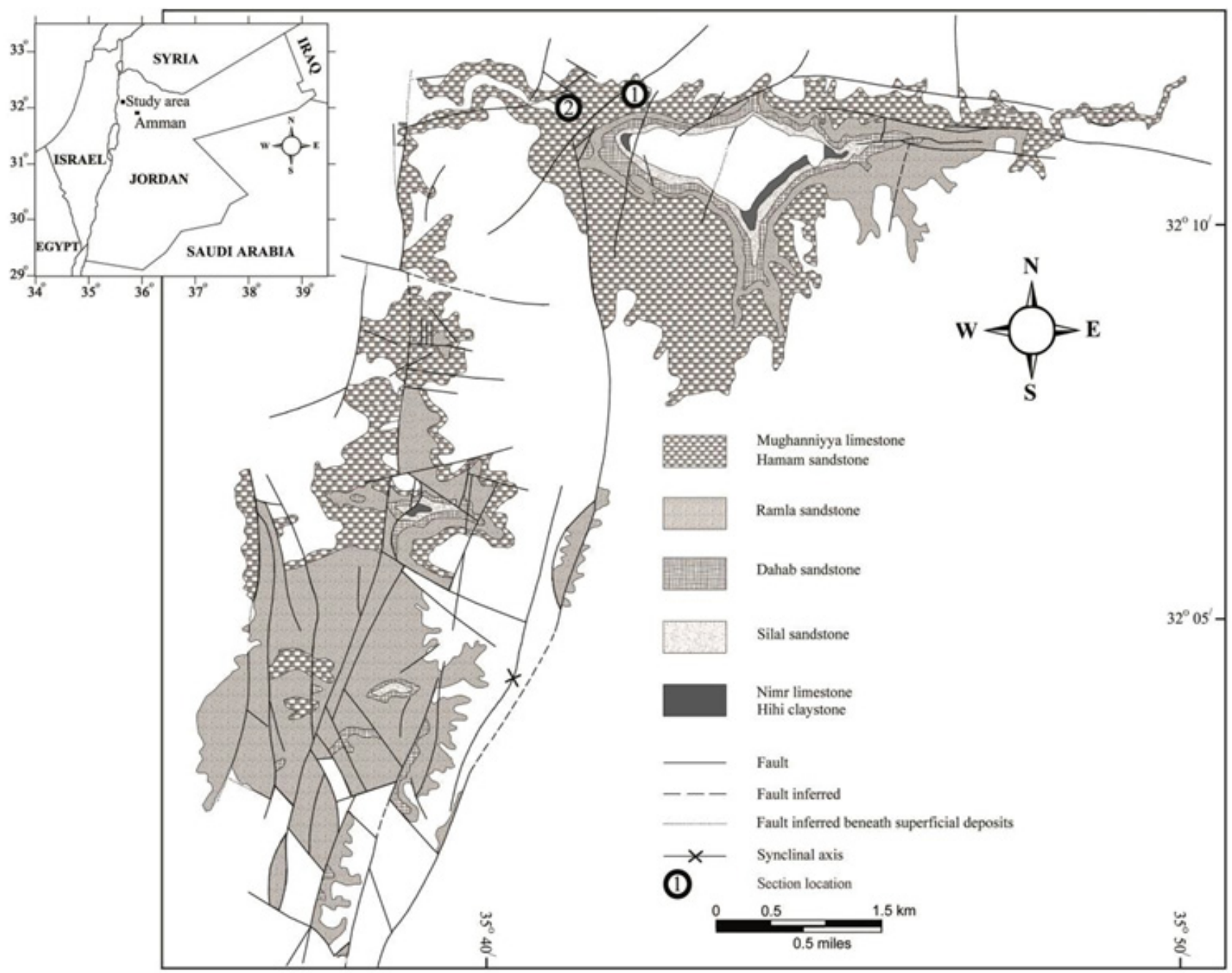

FIGURE 1 Geographical map of the study area, Wadi Zarqa, with collecting localities indicated. 
Daghanirhynchia daghaniensis, from Ethiopia because the shells were silicified and the composition of shell and sediment matrix allowed sufficient contrast for adequate images. Computer tomographical data were taken with a Phoenix / X-Ray with a 180kV high-power nanofocus tube and a tungsten target using a scanning distance between 10 and $35 \mu \mathrm{m}$. Serial sections were prepared using a Struers Discoplan-TS grinding machine with slice-spacing of 50 or $100 \mu \mathrm{m}$ starting from apex in an anterior direction perpendicular to commissural plane. Grinding surfaces were subsequently digitized using a digital camera (Canon 300D). Three-dimensional reconstruction methods are those of Sutton et al. (2001, 2005), using the custom SPIERS software suite for registration, virtual preparation, and interactive visualization. The photos of the grinding surfaces were subsequently manually aligned with SPIERSalign. In a second step, photos and CT (Computed Tomography) images were edited using different masks in SPIERSedit. The obtained 3D images were copied out of SPIERSview. Drawings of the peels were made with the help of a camera lucida. Measurements were taken with a digital caliper and rounded to $0.1 \mathrm{~mm}$ or using free ImageJ $1.43 \mu$ software. Specimens were coated with ammonium chloride or magnesium oxide prior to photographing. The systematics follows the revised Treatise on Invertebrate Palaeontology (Part H, no. 4); taxonomic assignments follow (Manceñido et al., 2002). Specimens are in repository at the American Museum of Natural History, New York, the Geological Survey of Israel, Jerusalem, the Natural History Museum, London, The Museum für Naturkunde, Berlin, and the United States National Museum of Natural History/Smithsonian Institution, Washington.

\section{Institutional abbreviations}

AMNH: American Museum of Natural History, New York, USA; MB.B.: Museum für Naturkunde Berlin, Germany;

GSI: Geological Survey of Israel, Jerusalem, Israel;

NHM: Natural History Museum, London, UK;

USNM: United States National Museum of Natural History/Smithsonian Institution, Washington DC, USA.

\section{Systematic paleontology}

Phylum BRACHIOPODA Duméril, 1806

Subphylum RHYNCHONELLIFORMEA Williams et
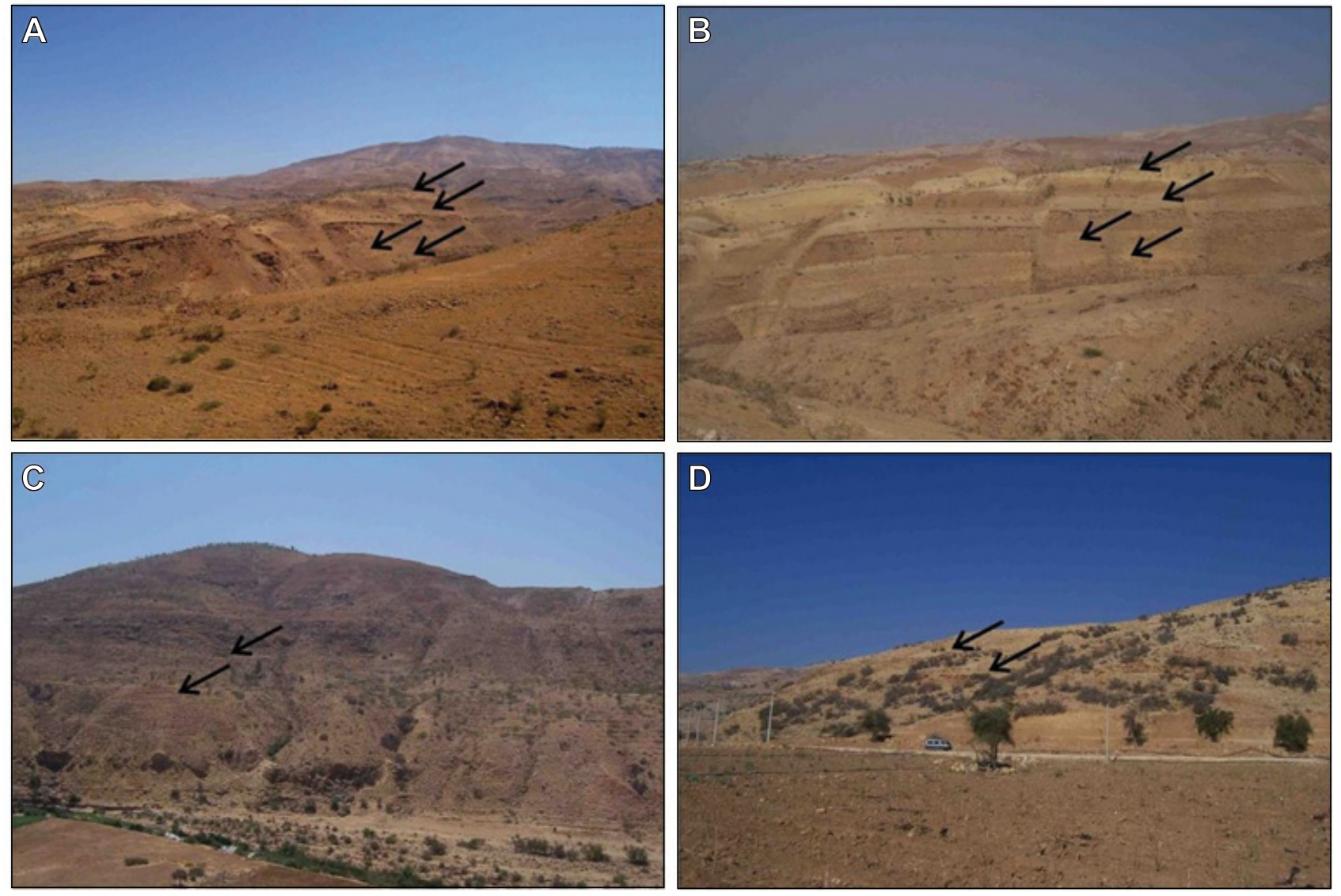

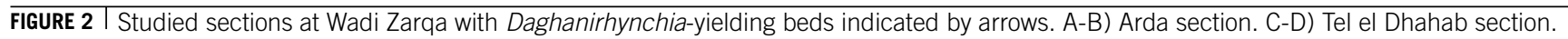


al. 1996

Class RHYNCHONELLATA Williams et al. 1996

Order RHYNCHONELLIDA Kuhn, 1949

Superfamily HEMITHYRIDOIDEA Rzhonsnitskaya, 1956

Family TETRARHYNCHIIDAE Ager, 1965

Subfamily TETRARHYNCHIINAE Ager, 1965

Genus Daghanirhynchia Muir-Wood, 1935

v 1935 Daghanirhynchia-Muir-Wood, p. 82-83.

v 1989 Daghanirhynchia. - Cooper, p. 26.

v 1993 Daghanirhynchia. - Shi and Grant, p. 73.

Type species. Daghanirhynchia daghaniensis MuirWood, 1935: 82; by original designation.

Emended diagnosis (from Muir-Wood, 1935). Shells medium-sized, subtriangular to subpentagonal, subglobose, dorsibiconvex, and often with large and curved ventral beak. Uniplicate and with distinct dorsal fold. Lateral commissure straight. Three to 6 costae on fold. Sulcus tongue high and trapezoidal. Beak acute, erect to incurved. Foramen large, circular to elongate elliptical. Deltidial lamellae lacking. Dental plates strong. Dorsal median septum weak, persistent. Hinge plate divided. Septalium usually pendant. Crura nearly horizontal, raduliform, and slightly to strongly incurved ventrally. Slightly modified after Manceñido et al. (2002, 1347).

Stratigraphical and geographical occurrence. Bathonian to Oxfordian (Middle to Upper Jurassic) (Manceñido et al., 2002, 1347); Somalia, Kenya, Ethiopia, Jordan, Egypt (Sinai), Arabia, Israel, Syria, India; questionable Morocco, Tunisia.

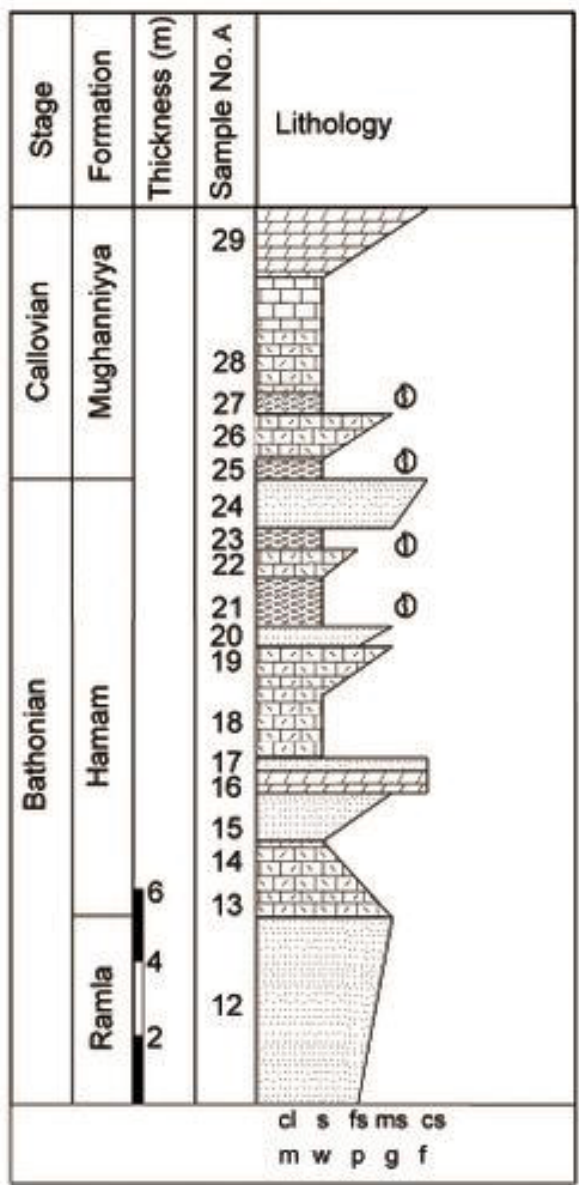

Arda Section
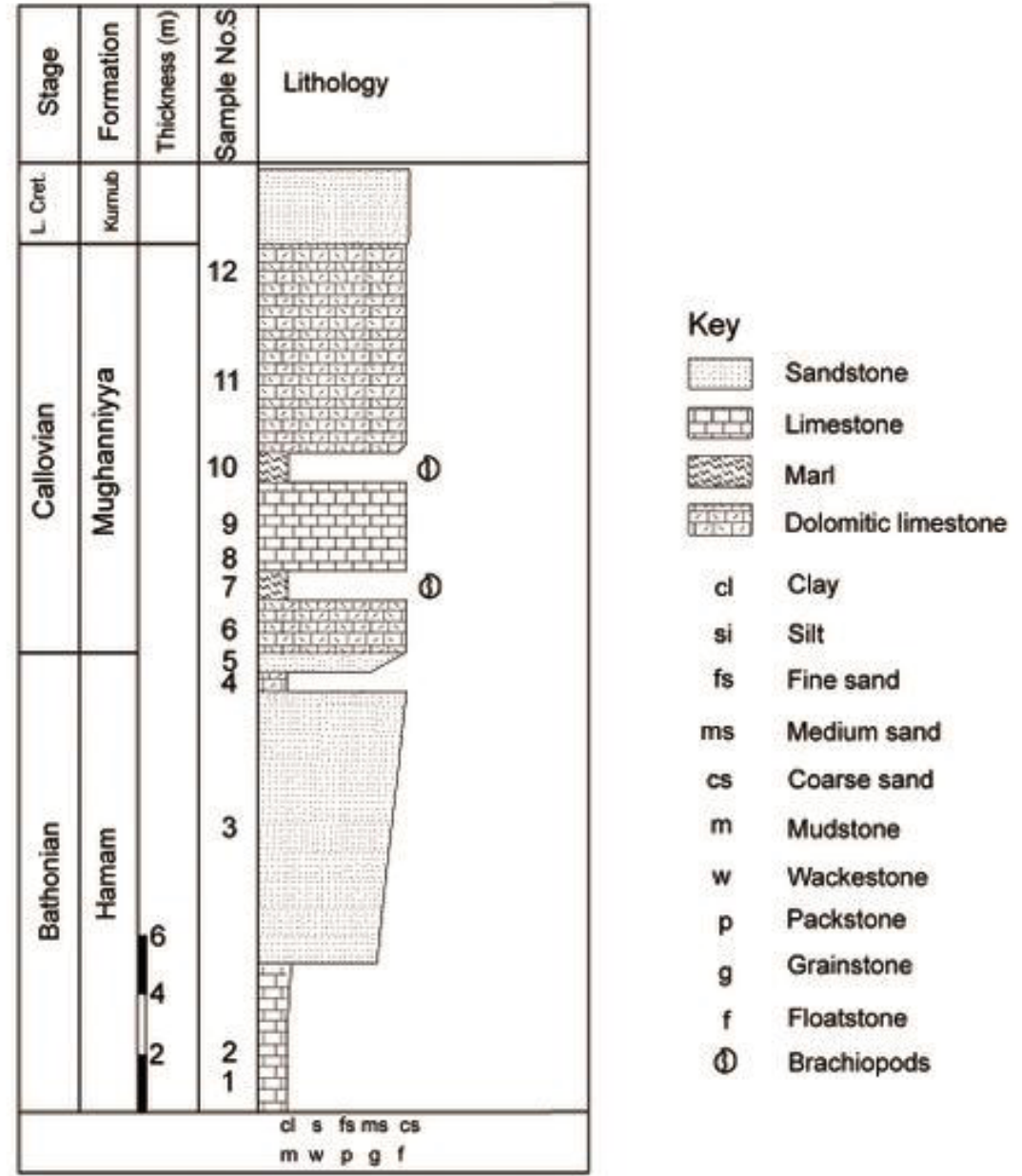

FIGURE 3 Stratigraphical columns of the sections sampled showing lithology and Daghanirhynchia-yielding beds. A) Arda section. B) Tel el Dhahab section. 


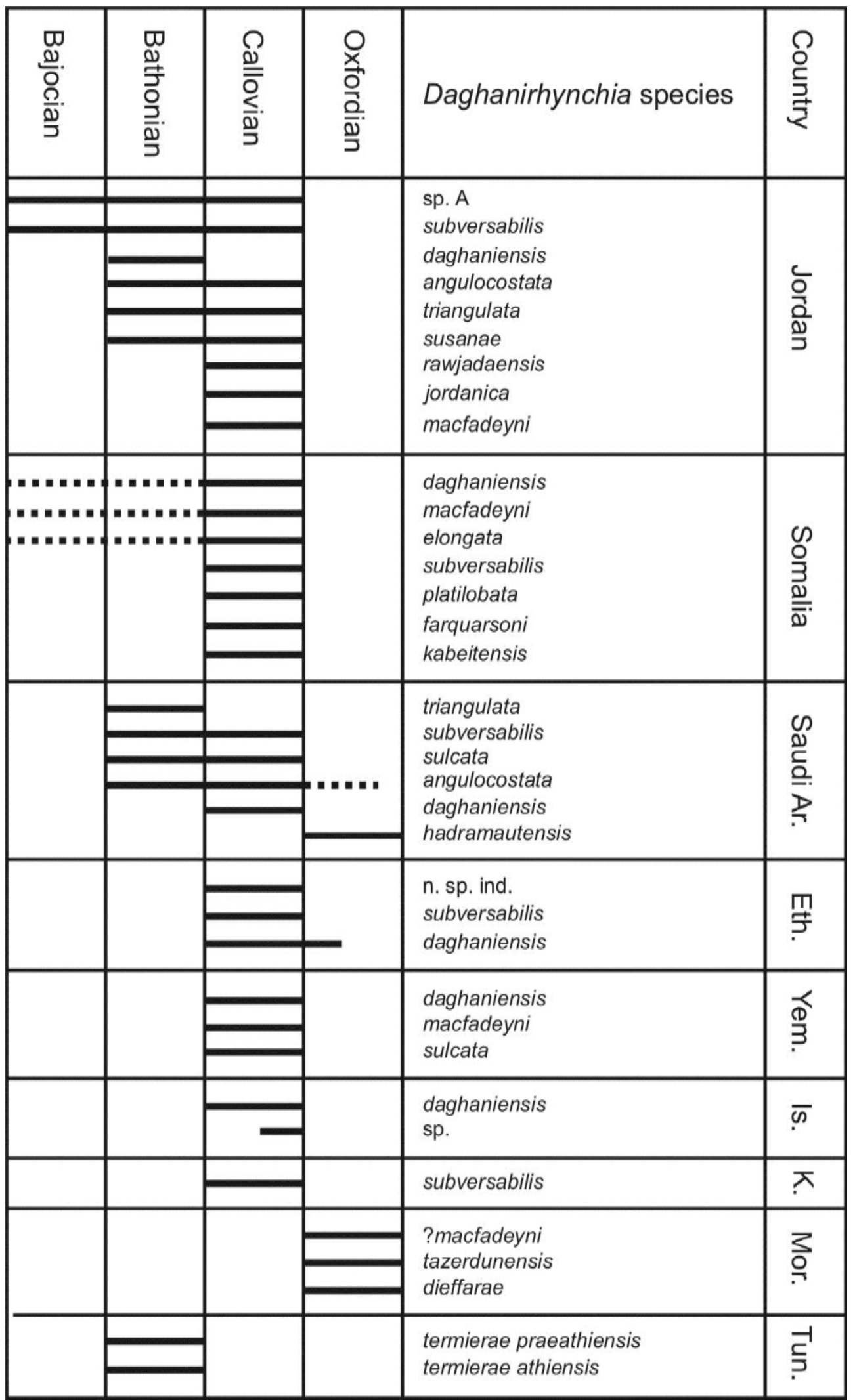

FIGURE 4 Stratigraphical and geographical distribution of Daghanirhynchia taxa from the Ethiopian Province (Cooper, 1989; Dubar, 1967; Feldman et al. 2001, 2012a, 2012b; Muir-Wood, 1935; Rousselle, 1965; Stefanini, 1925; Weir, 1925, 1929). Eth.: Ethiopia, Is.: Israel, K.: Kenya, Mor.: Morocco, Saudi Ar.: Saudi Arabia, Tun.: Tunisia, Yem.: Yemen. 


\section{Species included}

Daghanirhynchia daghaniensis Muir-Wood, 1935;

?Rhynchonella hadramautensis Stefanini, 1925;

Somalirhynchia subversabilis Weir, 1925;

Daghanirhynchia daghaniensis var. elongata MuirWood, 1935;

Daghanirhynchia daghaniensis var. platilobata MuirWood, 1935;

Daghanirhynchia farquarsoni Muir-Wood, 1935;

Daghanirhynchia kabeitensis Muir-Wood, 1935;

Daghanirhynchia macfadyeni Muir-Wood, 1935;

Rhynchonella (Daghanirhynchia) n. sp. ind. sensu Jaboli, 1959;

?Burmirhynchia termierae preathiensis Rouselle, 1965;

?Burmirhynchia termierae atheniensis Rouselle, 1965;

?Rhynchonella tazerdunensis Dubar, 1967;

?Rhynchonella dieffarae Dubar, 1967;

Daghanirhynchia angulocostata Cooper, 1989;

Daghanirhynchia sulcata Cooper, 1989;

?Daghanirhynchia triangulata Cooper, 1989

Daghanirhynchia susanae Feldman et al. 2012b;

Daghanirhynchia rawyaensis [described herein];

Daghanirhynchia jordanica [described herein].

Discussion. Species of Daghanirhynchia are mostly defined based on external morphology rather than on internal features. Serial sections of $D$. daghaniensis and $D$. angulocostata are given in Muir-Wood (1935) and Cooper (1989). In an earlier work (Feldman et al., 2012b) we showed serial sections of $D$. susanae which are re-figured herein. Serial sections of D. macfadyeni from the MuirWood collection housed in the NHM were taken and a CT scan of D. daghaniensis from Ethiopia was prepared. Owing to strong homoeomorphy we recommend the erection of new taxa based on internal and external shell morphology. For comparison the diagnoses, stratigraphical and geographical distribution of all Daghanirhynchia species are given, but further description is omitted due to lack of (internal) information. We could not study the specimens from Jaboli (1959), Rousselle (1965), and Dubar (1967), therefore, species assignment to Daghanirhynchia is noted with a question mark; these were noted by Cooper (1989) and Shi and Grant (1993).

\section{Daghanirhynchia rawyaensis $\mathrm{n}$. $\mathrm{sp}$.}

Figs. 5C; 6B; $7 ; 8$

Derivatio nominis. After Rawya Fayez, wife of F. Ahmad, for her assistance in the field.

Holotype. Articulated shell stored at the AMNH under the repository number AMNH FI-86469; length 24.6mm, width $29.2 \mathrm{~mm}$, and thickness $25.4 \mathrm{~mm}$.
Type horizon and type locality. Wadi Zarqa, Arda Section, Bed S-7, Mughanniyya Formation, Callovian (upper Middle Jurassic), Jordan.

Material. 18 articulated shells. Age: Callovian (upper Middle Jurassic). Locality: beds Arda 21b, Arda 23, Arda 25, Arda 27, S-7, S-10. Locality: Wadi Zarqa. AMNH 86469 (holotype), 86485-86494.

Diagnosis. Daghanirhynchia with 11 to 15 costae on each shell, 3 to 4 in the sulcus and 4 to 5 on the fold, thick and divergent dental plates, a long and thick dorsal median septum, raduliform crura, wedge-like dental plates.

Description. Shells medium-sized subpentagonal, dorsibiconvex with maximum width at midlength. Apical angle is 99 degrees. Eleven to 15 costae on each valve, of which 3 to 4 are in the sulcus and 4 to 5 on the fold. Costae simple and angular in cross-section. Fold and sulcus originating at midlength of shell. Sulcus tongue high, reaching maximum curvature of dorsal valve, and with rounded to rarely straight anterior margin. Beak erect and incurved in adult specimens. Dorsal interarea concealed.

Interior of ventral valve. Moderate development of secondary shell material in the apical region slightly filling the umbonal cavities (see Fig. 5C). Dental plates thick, divergent, and wedge-like posteriorly leading into massive teeth that are oriented in a dorsal direction. Denticular cavities rounded in cross-section (Figs. 5C; 7).

Interior of dorsal valve. Moderate development of secondary shell material. Dorsal median septum long, pronounced, and thick. Septalium lacking or imbedded into secondary shell material. Dental sockets rounded in cross-section, inner socket ridges straight. Hinge plates arched leading into short raduliform crura that are slightly curved ventrally.

Stratigraphical and geographical occurrence. Wadi Zarqa, Arda Section, Beds S-7, S-10, 21b, 23, 25, 27, Mughanniyya Formation, Callovian (upper Middle Jurassic), Jordan.

Discussion. Daghanirhynchia rawyaensis differs from D. jordanica in 1 to 2 costae less on fold and sulcus, gently more development of secondary shell material, thick and divergent dental plates, and a longer and thick dorsal median septum.

Daghanirhynchia rawyaensis n. sp. has 6 costae less on each valve than $D$. daghaniensis; the sulcus shows 1 rib less and the fold 1 to 2 costae less than in the type species. Daghanirhynchia daghaniensis has a short and fine dorsal median septum, whereas $D$. rawyaensis has a long and 
thick dorsal median septum. The crura of the type species extends further in a ventral direction than the crura of $D$. rawyaensis.
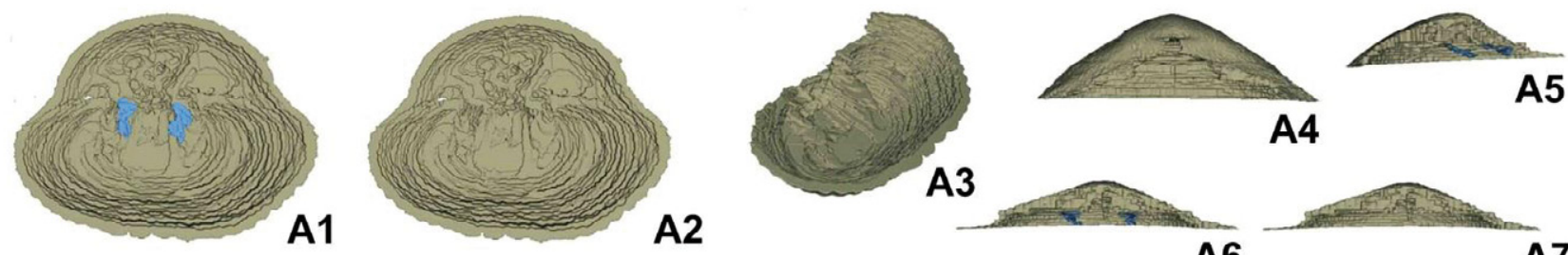

A4

A3
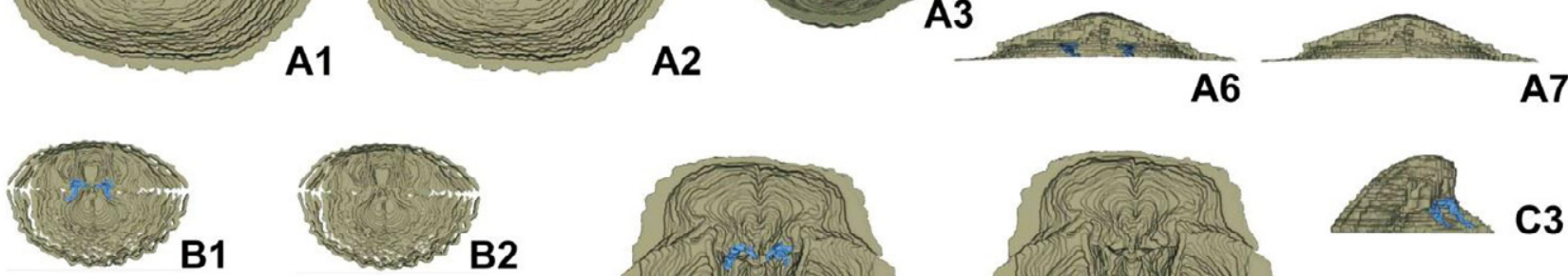

B2

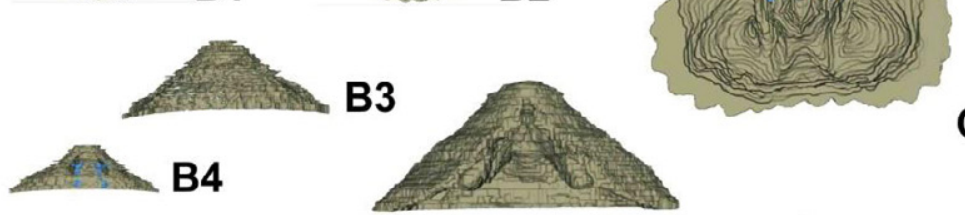

C1
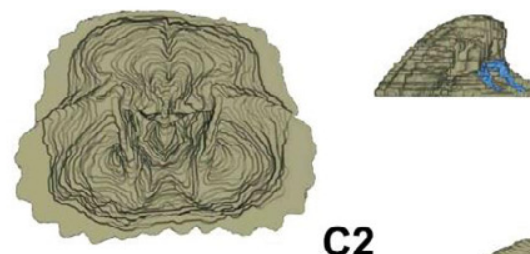

C3

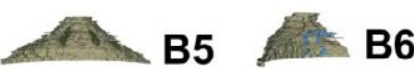

C4

B6
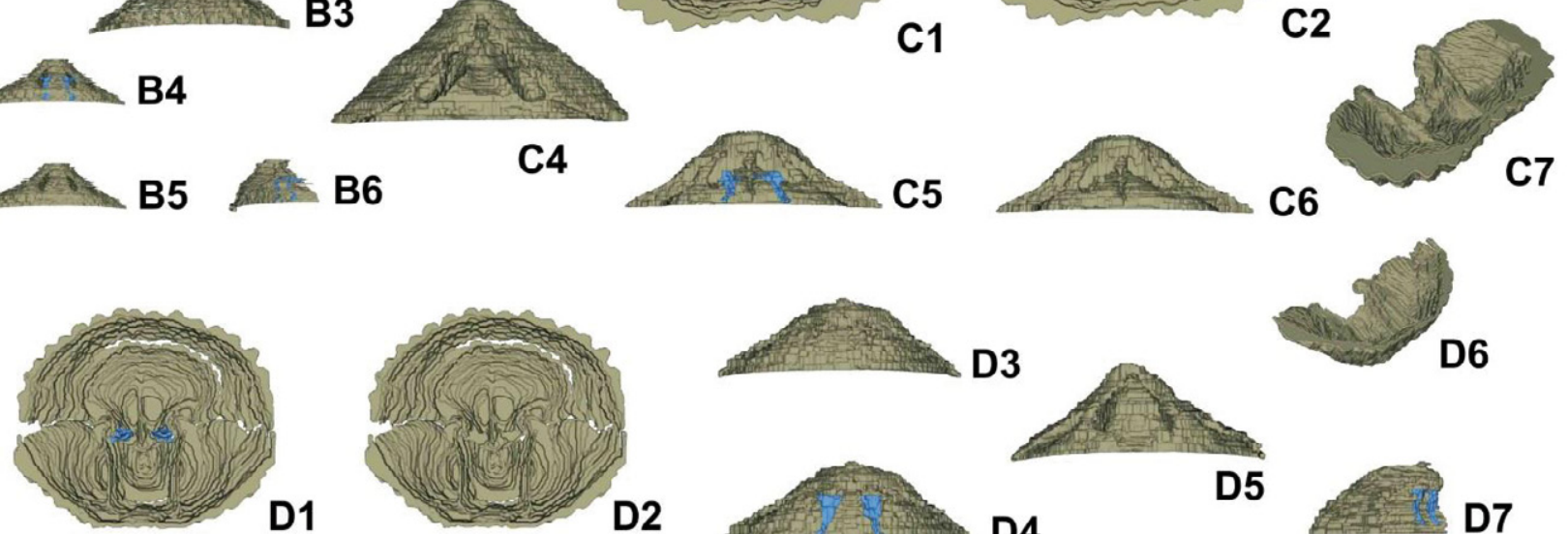

D3

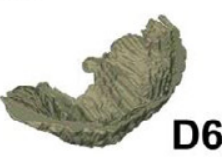

D2

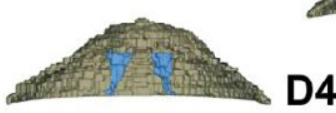

D5

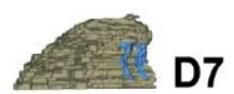

E1
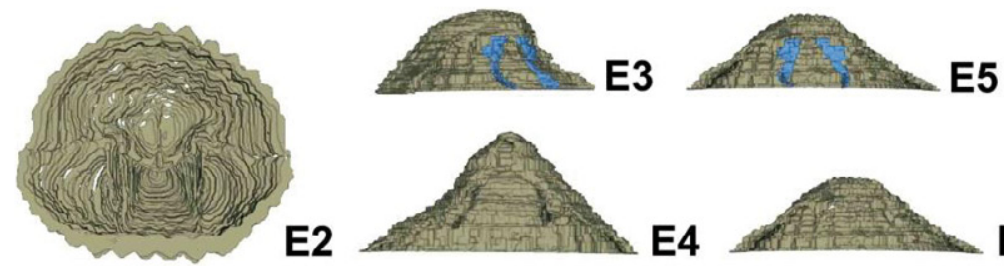

E4
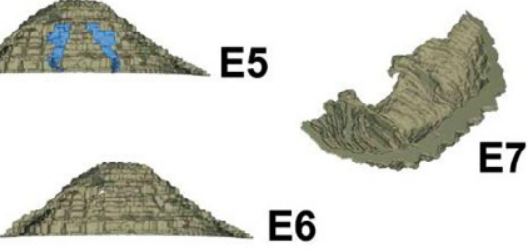

FIGURE 5 Three-dimensional reconstructions of Daghanirhynchia species after A) CT images and B-E) serial sections of articulated shells. All figures magnified (x2.0); scale bar 10mm. A) Daghanirhynchia daghaniensis Muir-Wood, 1935 (MB.B. 3358) from the Antalo. Limestone, Callovian/Oxfordian boundary interval from Geyedamo River, Mekele Outlier, Ethiopia. Anterior view of internal apical region of articulated shells A1) with and A2) without crura. A3) Oblique posterolateral and A4) dorsal views of internal ventral shell. A5) Oblique venterolateral and ventral views A6) with and A7) without crura of internal dorsal shell. B) Daghanirhynchia susanae Feldman et al. (2012b) (AMNH FI-72410) from Bed S-7, Mughanniyya Formation, Callovian, Arda section, Jordan. Anterior view of internalapical region of articulated shells B1) with and B2) without crura. B3) Dorsal view of internal ventral shell. Ventral views B4) with and B5) without crura and B6) oblique venterolateral and of internal dorsal shell. C) Daghanirhynchia rawyaensis n. sp. (AMNH FI-86479) Bed S-7, Mughanniyya Formation, Callovian, Arda section, Jordan. Anterior view of internal apical region of articulated shells C1) with and C2) without crura. C3) Oblique venterolateral view of dorsal internal shell. C4) Dorsal view of internal ventral shell. Ventral views C5) with and C6) without crura of internal dorsal shell. C7) Oblique posterolateral view of internal ventral shell. D) Daghanirhynchia jordanica n. sp. (AMNH FI-86480) from Bed S-7, Mughanniyya Formation, Callovian, Arda section, Jordan. Anterior view of internal apical region of articulated shells D1) with and D2) without crura. Ventral view D3) with and D4) without crura of internal dorsal shell. D5) Dorsal and D6) oblique posterolateral views of internal ventral shell. D7) Oblique venterolateral view of dorsal internal shell. E) Daghanirhynchia macfadyeni Muir-Wood, 1935 (NHM B. 85416) from Dhruma Formation, Bathonian/Callovian boundary interval from Al Haddar near Riyadh, Saudi Arabia. Anterior view of internal apical region of articulated shells E1) with and E2) without crura. E3) Oblique venterolateral view of dorsal internal shell. E4) Dorsal view of ventral internal shell. Ventral view E5) with and E6) without crura of internal dorsal shell. E7) Oblique posterolateral views of internal ventral shell. 

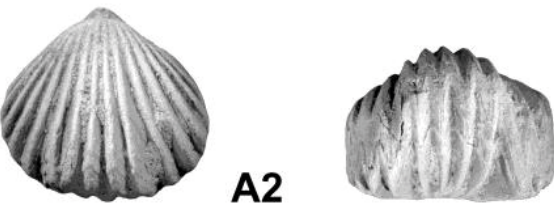

A3

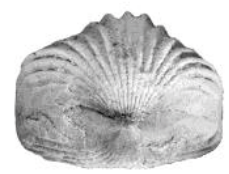

A4

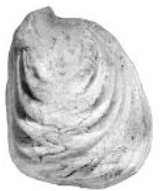

A5

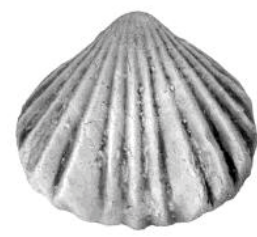

B1
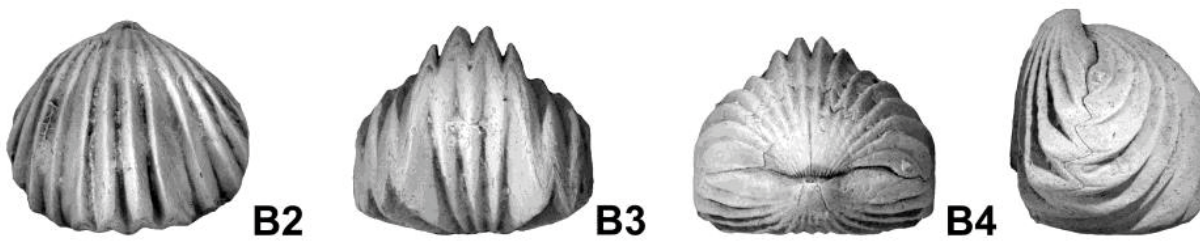

B5

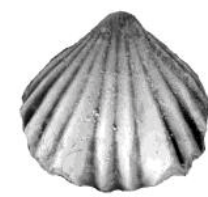

C1

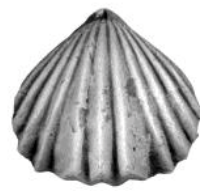

C2
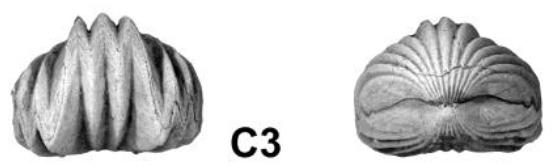

C4

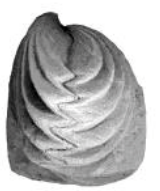

C5
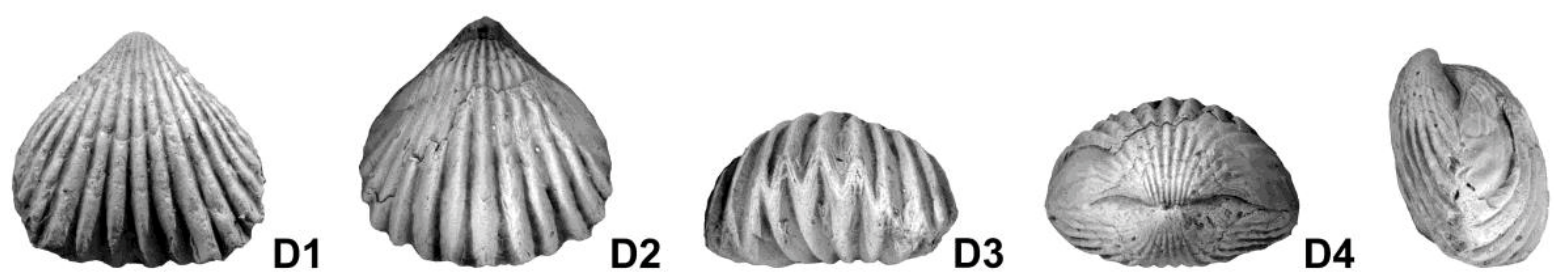

D5
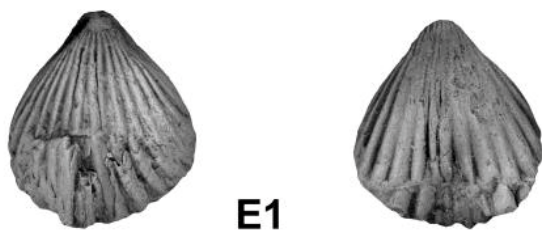

E2
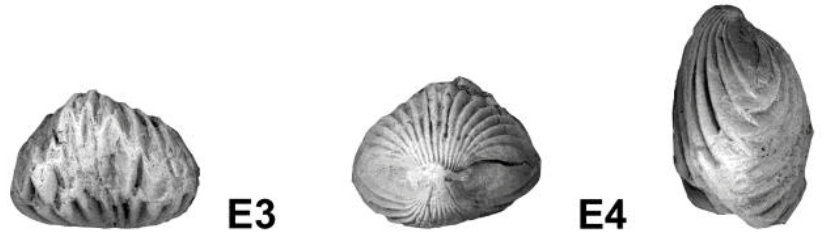

E5

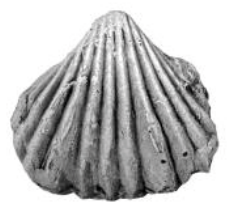

F1

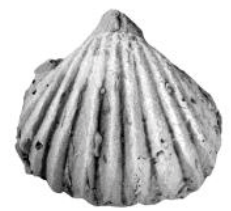

F2

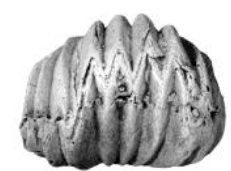

F3

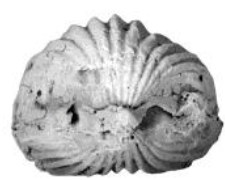

F4
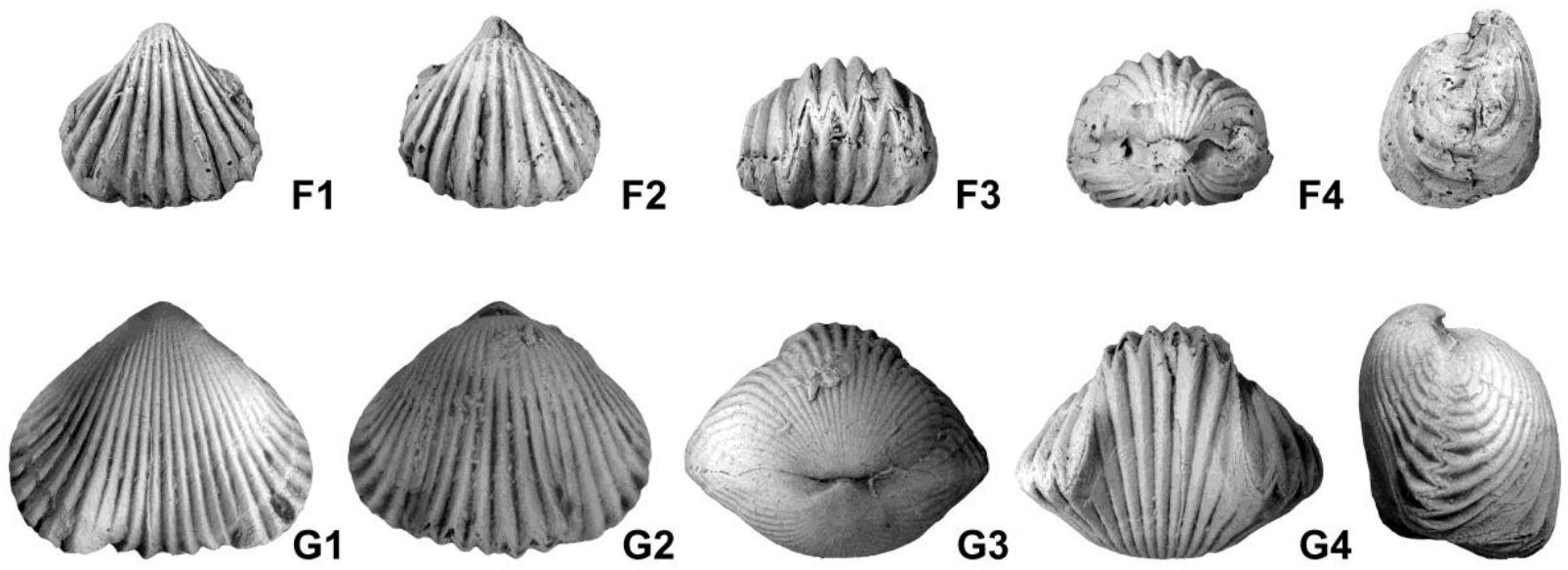

FIGURE 6 A) Daghanirhynchia jordanica n. sp. (AMNH FI-86481 from Wadi Zarqa, Arda Section, Bed S-7. B) Daghanirhynchia rawyaensis n. sp. (AMNH FI-86482) from Wadi Zarqa, Arda Section, Bed S-7, Mughanniyya Formation, Callovian (upper MiddleJurassic), Jordan. C) Daghanirhynchia susanae Feldman et al. (2012b) (AMNH Fl-72380) from Bed 7, Mughanniyya Formation, Callovian, Arda section, Jordan. D) Daghanirhynchia angulocostata Cooper, 1989 (AMNH FI-72395) from Bed S-7, Mughanniyya Formation, Callovian, Tel el Dhahab section, Jordan. E) ?Daghanirhynchia triangulata Cooper, 1989 (AMNH FI-72398) from Bed 21a, Hamam Formation, Bathonian, Arda section, Jordan. F) Daghanirhynchia macfadyeni Muir- Wood, 1935 (NHM B 85416) from Dhruma Formation, Bathonian/Callovian boundary interval, Al Haddar near Riyadh, Saudi Arabia. G) Daghanirhynchia daghaniensis Muir-Wood, 1935 (MB.B. 3358) from Antalo Limestone, Callovian/Oxfordian boundary interval, Geyedamo River, Mekel Outlier, Ethiopia. 1) Ventral, 2) dorsal, 3) anterior, 4) posterior, and 5) lateral views of articulated shells. All figures of original size (x1.0). 
secondary shell material, a subtriangular outline, thin and parallel dental plates, and a shorter dorsal median septum.

The shells of Daghanirhynchia susanae are smaller and have less secondary shell material, 1 to 2 costae less on fold and sulcus, thin dental plates, a short dorsal median septum, and longer crura than D. rawyaensis.

?Daghanirhynchia triangulata has a subriangular outline compared to D. rawyaensis. Daghanirhynchia angulocostata differs from D. rawyaensis in that there are 1 to 3 more costae on each shell and a thin dorsal median septum is present.

\section{Daghanirhynchia jordanica n. sp.}

Figs. 5D; 6A; 9; 10

Derivatio nominis. After the country Jordan in which the type locality is located; jordanica (= latinization, adj. of Jordan).
Holotype. Articulated shell housed at the AMNH under the repository number AMNH FI-86469; length $24.6 \mathrm{~mm}$, width $25.6 \mathrm{~mm}$, and thickness $21.4 \mathrm{~mm}$.

Type horizon and type locality. Wadi Zarqa, Arda Section, Bed S-7, Mughanniyya Formation, Callovian (upper Middle Jurassic), Jordan.

Material. 16 specimens. Age: Callovian (upper Middle Jurassic). Locality: beds Arda 21a, b, S-7, S-10. Locality: Wadi Zarqa. AMNH FI-86495 (holotype), FI-86496, FI86497 (5 pcs), FI-86498, FI-85499, FI-86500 (3 pcs), FI86501 (3 pcs), FI-86502.

Diagnosis. Daghanirhynchia with 14 to 16 costae on each shell, 4 to 5 in sulcus and 5 on fold. Hardly any development of secondary shell material, thin and parallel dental plates, and a high and blade-like dorsal median septum. Septalial plates are narrow and parallel to one another.

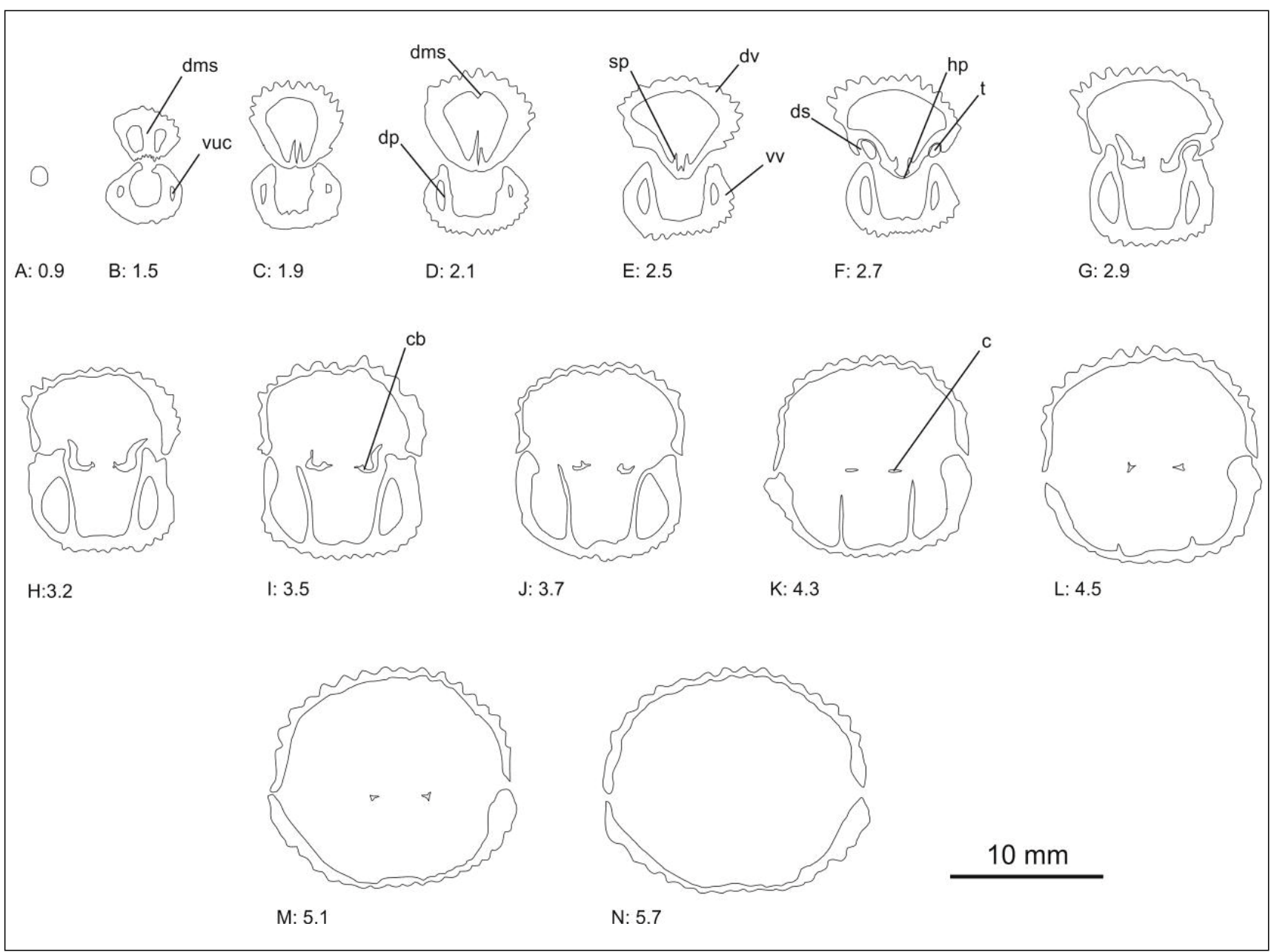

FIGURE 7 Drawings of grinding surfaces of serial sections perpendicular to commissural plane of articulated shell of Daghanirhynchia rawyaensis n. sp. 11Daghanirhynchia sp. 1, (AMNH FI-86483). Numbers show section distance from apex in mm. All figures magnified (x2.0). c: crus, cb: crural base, dms: dorsal median septum, dp: dental plate, ds: dental socket, dv: dorsal valve, t: tooth, vuc: ventral umbonal cavity, vv: ventral valve. 
Description. Shells medium-sized, subpentagonal, gently dorsibiconvex with maximum width at midlength of shell or anterior to it. Apical angle is 98 degrees. Shells covered by 14 to 16 simple and rounded to angular costae, of which are 4 to 5 in the sulcus and 5 on the fold. Sulcus and fold originating at midlength of shell. Sulcal tongue almost reaching maximum curvature of ventral valve and with rounded anterior margin. Ventral umbo moderately long and suberect. Dorsal interarea concealed.

Interior of ventral valve. Hardly any development of secondary shell material. Umbonal cavities free, ventral median septum lacking. Dental plates short, thin, and parallel to each other, leading into short and knob-like teeth that project dorsally.

Interior of dorsal valve. No development of secondary shell material. Dorsal median septum short and bladelike. Septalium weakly developed, hardly recognizable. Septalial plates narrow and parallel to one another. Dental sockets rounded in cross- section. Inner socket ridges show tendency to curve over dental sockets. Hinge plate arched leading into raduliform, slightly curved ventrally crura.

Stratigraphical and geographical occurrence. Wadi Zarqa, Arda Section, Beds S-7, S-10, 21a, Mughanniyya Formation, Callovian (upper Middle Jurassic), Jordan.

Discussion. Daghanirhynchia jordanica n. sp. has 3 to 5 costae less than the type species D. daghaniensis, but the amount of costae on fold and sulcus is the same. Furthermore, D. jordanica has hardly any development of secondary shell material, parallel and thin dental plates, a higher dorsal median septum, narrow and parallel septalial plates, and gently ventrally curved crura. Daghanirhynchia daghaniensis shows stronger development of secondary shell material, divergent dental plates, a lower dorsal median septum and septalial plates that are oriented almost parallel to each other. Daghanirhynchia jordanica has 2 to 4 less costae on each shell than D. macfadyeni, a subpentagonal outline, a higher dorsal median septum, and parallel septalial plates. Daghanirhynchia jordanica differs from D. susanae (see Fig. 11) in that it possesses 1 to 2 more costae, less secondary shell material, parallel dental plates, a higher dorsal median septum, and shorter crura. Daghanirhynchia angulocostata has 1 less costa on the sulcus and 1 more costa on the fold than D. jordanica. ?Daghanirhynchia triangulata shows a subtriangular outline and 1 to 2 costae less on fold and sulcus than $D$. jordanica.

\section{Daghanirhynchia daghaniensis Muir-Wood, 1935}

Figs. 5A; 6G

*v 1935 Daghanirhynchia daghaniensis Muir-Wood, p. 83-85, figs. 4-6, pl. 8 figs. 5a-c.

v 1959 Rhynchonella (Daghanirhynchia) daghaniensis. - Jaboli, p. 23-24, pl. 3 fig. 4a-d. v 1993 Daghanirhynchia daghaniensis. - Shi and Grant, p. 73-74, pl. 10 fig. 7, 44.

v 2011 Daghanirhynchia sp. - Kiessling et al. fig. 11P$\mathrm{T}$

Holotype. Articulated shell housed in the NHM under the repository number B.85408; length $26.1 \mathrm{~mm}$, width $28.2 \mathrm{~mm}$, and thickness $19.4 \mathrm{~mm}$.

Type horizon and type locality. Bed $\varphi .227$, Daghani section, Somalia (detailed description is given in MuirWood, 1935, table 2).

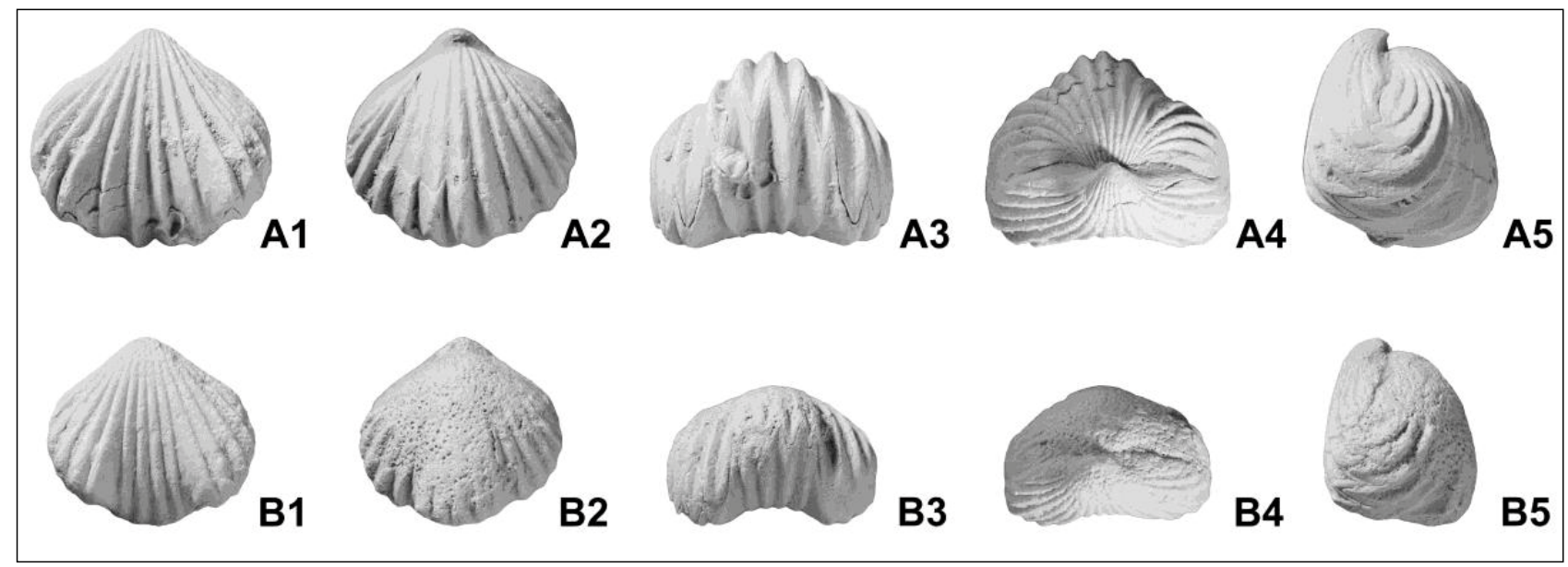

FIGURE 8 A. Daghanirhynchia rawyaensis n. sp. from Bed S-7, Mughanniyya Formation, Callovian, Tel el Dhahab section, Jordan. A) AMNH FI86469 Holotype. B) AMNH FI-86470. 1) Ventral, 2) dorsal, 3) anterior, 4) posterior, and 5) lateral views of articulated shells. All figures of original size $(x 1.0)$ 
Material. One silicified articulated shell (MB.B. 3358). Stratum: Antalo Limestone, Callovian/Oxfordian boundary interval. Locality: Geyedamo River, Mekele Outlier, Ethiopia.

Diagnosis. Dorsibiconvex Daghanirhynchia with subtriangular to subpentagonal outline and with moderate development of secondary shell material in the apical region of both valves. Costae coarse and subangular, 17 to 21 on each valve, with 3 to 6 on fold and 2 to 5 in the sulcus. Dental plates slightly divergent and dorsal median septum short. Septalium lacking or imbedded into secondary shell material.
Description. Shells medium-sized, subtrigonal to subpentagonal, and dorsibiconvex. Ventral valve posteriorly convex with maximum convexity at midvalve to anterior. Apical angle is 95 degrees. Numerous rounded costae, 17 to 21 on each valve, 3 to 6 on fold, 2 to 5 in sulcus. Sulcus well developed, broad, steep, with flattened bottom and beginning at posterior $1 / 3$ to $1 / 2$ part of shell. Sulcus tongue high, trapezoidal. Fold raised significantly over flanks, broad, pronounced, rounded at top, and starting at posterior $1 / 3$ to $1 / 2$ part of shell.

Exterior. Ventral beak long, massive, and suberect. Foramen large, subcircular to elongate elliptical,
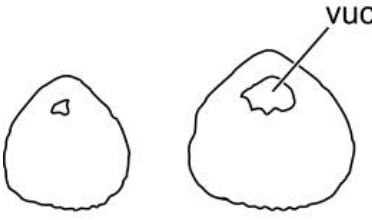

A: 1.20

B: 1.90

C: 2.44

D: 3.92

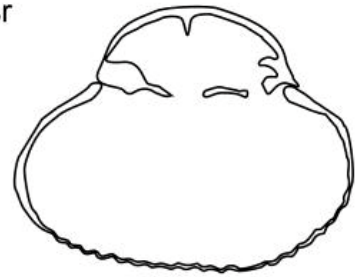

H: 5.63

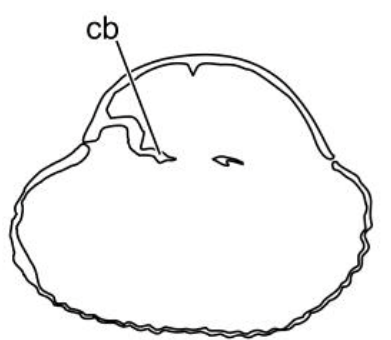

I: 6.27

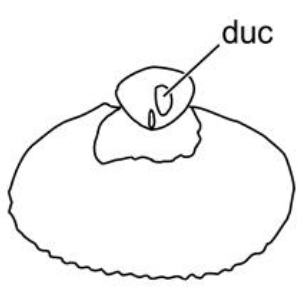

E: 4.17

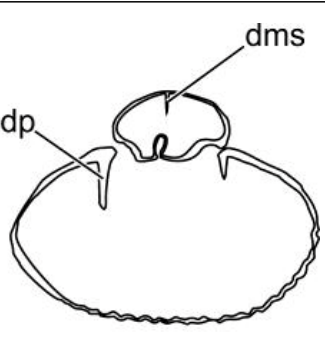

F: 4.68

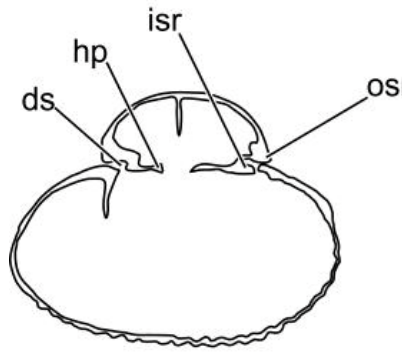

G: 5.26

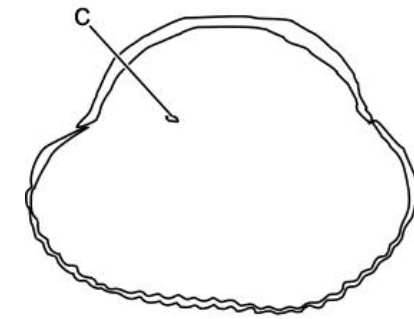

K: 7.00

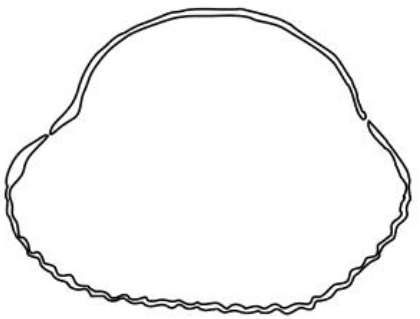

L: 7.36

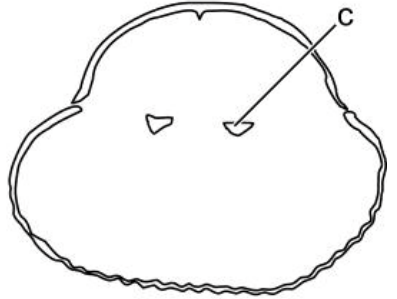

J: 6.69

FIGURE 9 Drawings of grinding surfaces of serial sections perpendicular to commissural plane of articulated shell of Daghanirhynchia jordanica $\mathrm{n}$. sp. [16Daghanirhynchia 5 costae] (AMNH Fl-86484). Numbers show section distance from apex in mm. All figures magnified (x2.0). c: crus, cb: crural base, dms: dorsal median septum, dp: dental plate, ds: dental socket, dv: dorsal vavle, hp: hinge plate, sp: septalial plate, t: tooth, vuc: ventral umbonal cavity, vv: ventral valve. 
hypothyrid with or without deltidial lamellae. Interareas small but distinct and gently curved.

Interior of ventral valve. Hardly any development of secondary shell material in the apical region. Ventral umbonal cavities small and narrow. Dental plates slightly divergent toward ventral valve floor, splitting away from floor just at hinge line, and leading into short, massive teeth rectangular in cross-section. Crenulation was not observed.

Interior of dorsal valve. Hardly any development of secondary shell material in the apical region. Dorsal median septum short and supporting hinge plates only at very posterior of apical cavity; it is preserved as a reduced ridge extending for about $1 / 4$ of valve length in an anterior direction. Septalium lacking, septalial plates very short. Hinge plates broad, clearly separated, slightly inclined or arched ventrally and tapering anteriorly. Inner socket ridges low, well demarcated from hinge plates. Crural bases not well formed, leading into raduliform crura that extend about $1 / 5$ of dorsal valve length almost protruding along commissural plane and only slightly incurved ventrally at distal ends. Crura arise from prolongations of hinge plate, relatively wide and somewhat similar to ciliform at preliminary parts in cross-section.

Stratigraphical and geographical occurrence. Bathonian to ?Oxfordian (Middle to ?lower Upper Jurassic); Yemen, Jordan, Saudi Arabia, Somalia, Ethiopia.

Discussion. Daghanirhynchia daghaniensis MuirWood, 1935 differs from all Daghanirhynchia taxa from Jordan in its larger shells and more numerous costae.

Daghanirhynchia susanae Feldman et al. (2012b) differs from $D$. daghaniensis in smaller shells, 5 ribs less
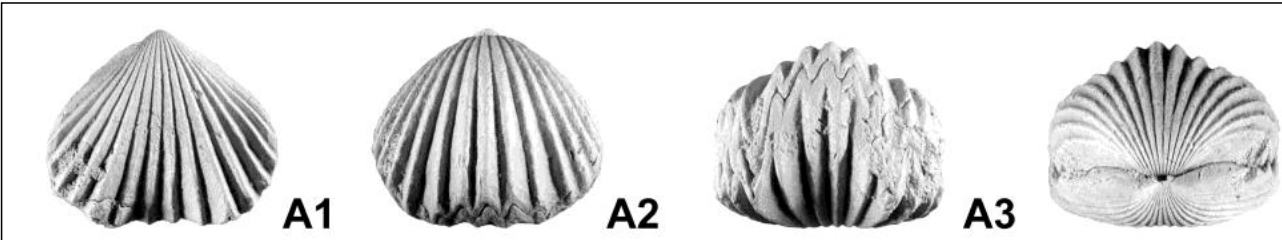

A4
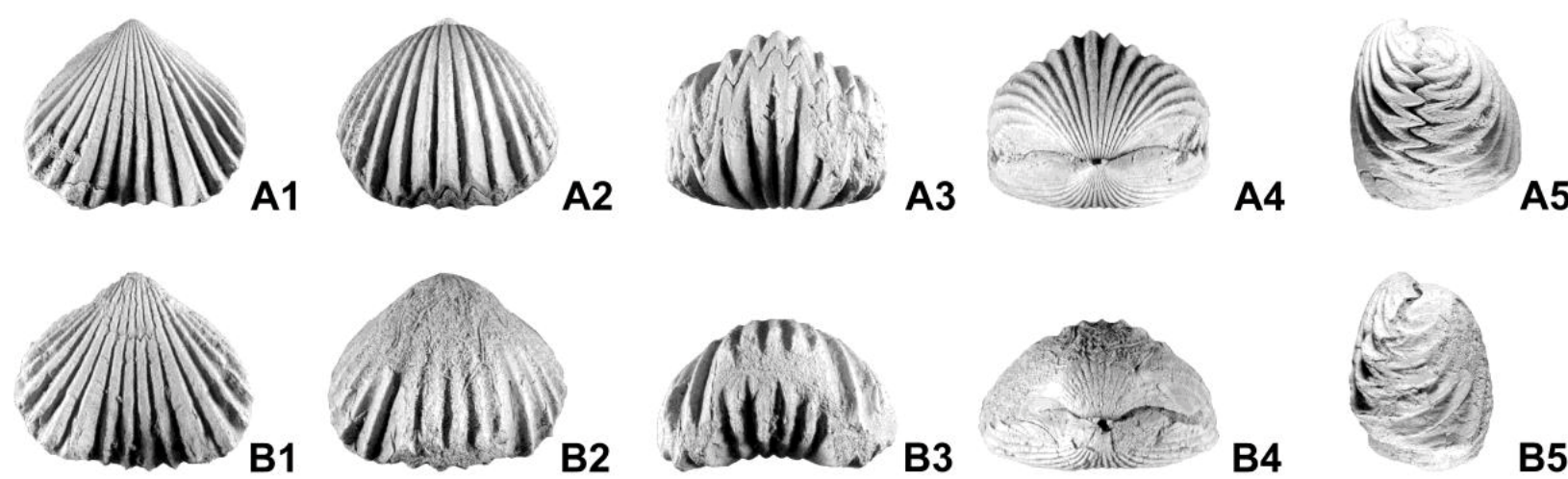

B2

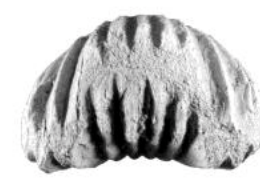

B3

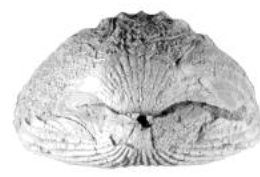

B4

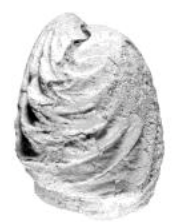

B5
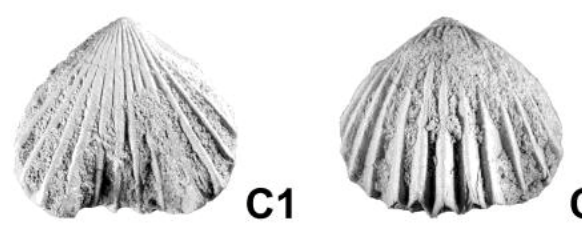

C2

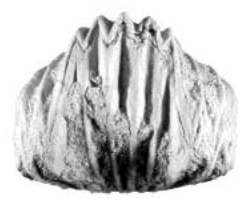

C3

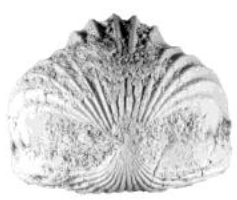

C4

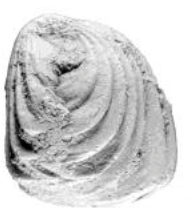

C5

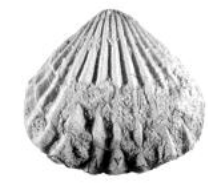

D1

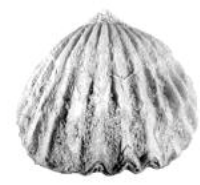

D2

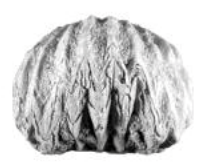

D3

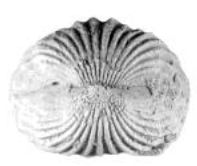

D4

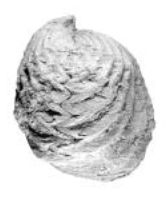

D5

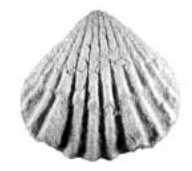

E1

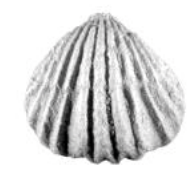

E2

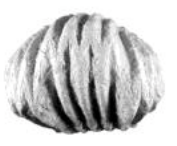

E3

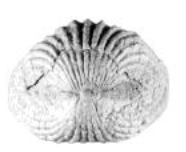

E4

FIGURE 10 Daghanirhynchia jordanica n. sp. from Wadi Zarqa, Arda Section, Bed S-7, Mughanniyya Formation, Callovian (upper Middle Jurassic), Jordan. A) AMNH Fl86469 (holotype). B) AMNH FI-86475. C) AMNH FI-86476. D) AMNH FI-86477. E) AMNH FI-86478. 1) Ventral, 2) dorsal, 3) anterior, 4) posterior, and 5) lateral views of articulated shells. All figures of original size (x1.0). 
on each valve, only 2 to 3 costae on fold and sulcus, less secondary shell material, parallel septalial plates, and long crura that are slightly curved ventrally.

Daghanirhynchia macfadyeni Muir-Wood, 1935 has almost the same number of costae, but less secondary shell material, a subtriangular outline, thin dental plates, a small and short septalium, and crura extending less distance in a ventral direction than in $D$. daghaniensis.

?Daghanirhynchia triangulata Cooper, 1989 has 1 to 3 less costae on each shell, less secondary shell material in the apical region, and a subtriangular outline. Daghanirhynchia angulocostata Cooper, 1989 has 3 to 5 less costae on each shell, a longer dorsal median septum and a small septalium.

A morphological comparison of Daghanirhynchia taxa from Jordan and the type species is given in Table 1.

\section{Daghanirhynchia macfadyeni Muir-Wood, 1935}

Figs. 5E; 6F; 12

v 1935 Daghanirhynchia macfadyeni Muir-Wood, p. 88-89, pl. 8 figs. 7 a-c.

v 2012b Daghanirhynchia macfadyeni - Feldman et al., p. 199.

Holotype. Articulated shell housed in the NHM under the repository number NHM B85416; length $26.5 \mathrm{~mm}$, width $25.7 \mathrm{~mm}$, and thickness $21.4 \mathrm{~mm}$.
Type horizon and type locality. Bed 226, Daghani section, near Bihendula, Somalia (detailed description is given in Muir-Wood, 1935, table 2).

Material. 1 articulated shell (NHM B. 85416). Age: Callovian (upper Middle Jurassic). Locality: Daghani section, Somalia. 120 articulated shells. Age: Callovian (upper Middle Jurassic), beds Arda 21a, b, 23, 27, S-7, S-10. Locality: Wadi Zarqa: AMNH FI-86503-86526, Strata: Callovian (upper Middle Jurassic), beds unknown. Locality: Wadi Zarqa: GSI M734, GSI M2974, GSI M4506 (2pcs.), GSI M4552 (2pcs), GSI M4557 (4pcs), GSI M4558.

Emended diagnosis. Daghanirhynchia with subtrigonal shell outline, strongly dorsibiconvex with low median fold and broad shallow sulcus, ornamentation consists of 18 strong and angular costae, with 4 to 5 on fold and 3 to 4 in sulcus, and anterior commissure significantly thickened in adult specimens. After Muir-Wood (1935, 88).

Description. Shells medium to large, subtriangular and strongly dorsibiconvex. Ventral valve convex posteriorly, medially flattened. Slightly longer than wide with maximum width at midlength. Apical angle is 94 degrees. Fold low, sulcus broad and shallow at anterior margin. Eighteen costae on each valve, 4 to 5 in fold, 3 to 4 on sulcus. Costae coarse, prominent angular and curved on flanks. Sulcus tongue broad and rectangular. Ventral umbo long and strongly incurved in adult specimens. Interareas narrow, flattened, and smooth. Anterior commissure deflected

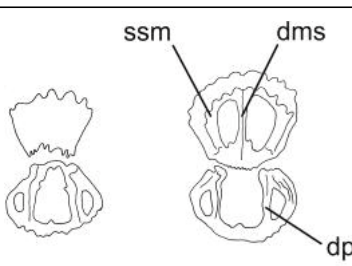

A. 0.8

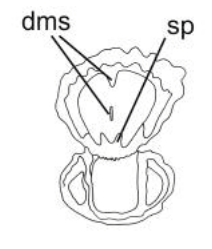

C: 1.3

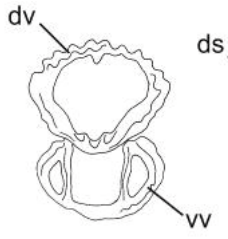

D: 1.5

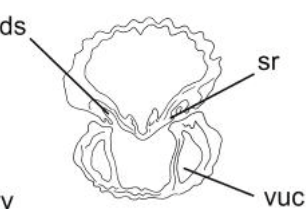

E: 1.8

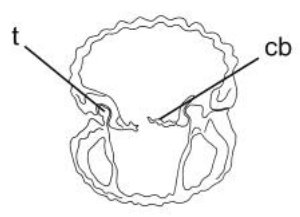

$\mathrm{F}: 2.2$

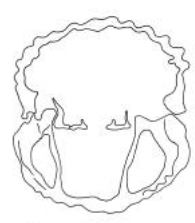

G: 2.5

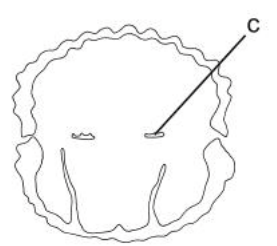

H: 2.9

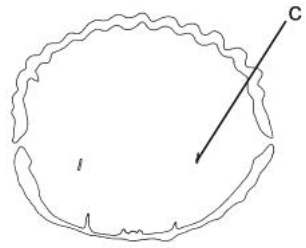

I: 3.7

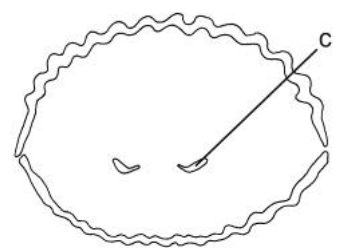

J: 4.3

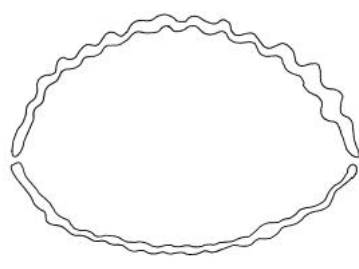

K: 4.6

FIGURE 11 Drawings of grinding surfaces of serial sections perpendicular to commissural plane of articulated shell of Daghanirhynchia susanae Feldman et al. (2012b) (AMNH 72410). Numbers show section distance from apex in mm. All figures magnified (x2.0). c: crus, cb: crural base, dms: dorsal median septum, dp: dental plate, ds: dental socket, dv: dorsal valve, sp: septalial plate, sr: socket ridges, ssm: secondary shell material, t: tooth, vuc: ventral umbonal cavity, vv: ventral valve. 
TABLE 1 Morphological comparison of Daghanirhynchia species from the Jordan Valley

\begin{tabular}{|c|c|c|c|c|c|c|c|}
\hline & $\begin{array}{c}\text { D. } \\
\text { rawjadae } \\
\text { nsis n. sp. }\end{array}$ & $\begin{array}{c}\text { D. } \\
\text { jordanica a } \\
\text { n. sp. }\end{array}$ & $\begin{array}{c}\text { D. } \\
\text { daghanie nsis } \\
\text { Muir- Wood, } \\
1935\end{array}$ & $\begin{array}{c}D . \\
\text { susanae } \\
\text { Feldman et } \\
\text { al., 2012b }\end{array}$ & $\begin{array}{c}D . \\
\text { macfadyen } \\
i \text { Muir- } \\
\text { Wood, } \\
1935\end{array}$ & $\begin{array}{c}\text { ?D. } \\
\text { triangul ata } \\
\text { Cooper, } \\
1989\end{array}$ & $\begin{array}{c}D . \\
\text { angulocos } \\
\text { tata Cooper, } \\
1989\end{array}$ \\
\hline size & medium & medium & $\begin{array}{l}\text { medium to } \\
\text { large }\end{array}$ & $\begin{array}{l}\text { small to } \\
\text { medium }\end{array}$ & $\begin{array}{l}\text { medium } \\
\text { to large }\end{array}$ & medium & medium \\
\hline outline & $\begin{array}{c}\text { subpentago } \\
\text { nal }\end{array}$ & $\begin{array}{l}\text { subpentag } \\
\text { onal }\end{array}$ & $\begin{array}{l}\text { subtriangul } \\
\text { ar to } \\
\text { subpentag } \\
\text { onal }\end{array}$ & $\begin{array}{l}\text { subpentag } \\
\text { onal }\end{array}$ & $\begin{array}{l}\text { subtriang } \\
\text { ular }\end{array}$ & $\begin{array}{l}\text { subtriang } \\
\text { ular }\end{array}$ & $\begin{array}{c}\text { subpentago } \\
\text { nal }\end{array}$ \\
\hline $\begin{array}{l}\text { apical } \\
\text { angle }\end{array}$ & & & $95^{\circ}$ & & $80^{\circ}$ & & \\
\hline $\begin{array}{l}\text { no } \\
\text { costae/sh ell }\end{array}$ & 11 to 15 & 14 to 16 & 17 to 21 & 12 to 16 & 18 & 16 to 18 & 14 to 16 \\
\hline $\begin{array}{l}\text { no costae/su } \\
\text { lcus }\end{array}$ & 3 to 4 & 4 to 5 & 2 to 5 & 2 to 3 & 3 to 4 & 2 to 3 & 3 to 4 \\
\hline $\begin{array}{l}\text { no } \\
\text { costae/fo ld }\end{array}$ & 4 to 5 & 5 & 3 to 6 & 3 & 4 to 5 & 3 to 4 & 4 to 6 \\
\hline $\begin{array}{l}\text { secondar } \\
\text { y shell } \\
\text { material } \\
\end{array}$ & moderate & hardly & moderate & few & hardly & $?$ & $?$ \\
\hline $\begin{array}{l}\text { dental } \\
\text { plates }\end{array}$ & $\begin{array}{c}\text { thick } \\
\text { divergent }\end{array}$ & $\begin{array}{c}\text { thin } \\
\text { parallel }\end{array}$ & $\begin{array}{l}\text { posteriorly } \\
\text { thickened } \\
\text { divergent }\end{array}$ & $\begin{array}{c}\text { thick } \\
\text { divergent }\end{array}$ & $\begin{array}{c}\text { thin } \\
\text { parallel }\end{array}$ & $?$ & $?$ \\
\hline $\begin{array}{l}\text { dorsal } \\
\text { median } \\
\text { septum } \\
\end{array}$ & $\begin{array}{l}\text { long } \\
\text { thick }\end{array}$ & $\begin{array}{c}\text { short } \\
\text { blade-like }\end{array}$ & $\begin{array}{l}\text { short } \\
\text { fine }\end{array}$ & $\begin{array}{l}\text { short } \\
\text { fine }\end{array}$ & $\begin{array}{l}\text { short } \\
\text { fine }\end{array}$ & $?$ & $?$ \\
\hline $\begin{array}{l}\text { septaliu } \\
\text { m }\end{array}$ & imbedded & $\begin{array}{c}\text { weakly } \\
\text { developed }\end{array}$ & imbedded & imbedded & $\begin{array}{c}\text { small, } \\
\text { short }\end{array}$ & $?$ & small \\
\hline $\begin{array}{l}\text { septalial } \\
\text { plates }\end{array}$ & imbedded & $\begin{array}{l}\text { narrow, } \\
\text { parallel }\end{array}$ & $\begin{array}{l}\text { short, } \\
\text { almost } \\
\text { parallel }\end{array}$ & parallel & $\begin{array}{l}\text { almost } \\
\text { parallel }\end{array}$ & $?$ & $?$ \\
\hline crura & $\begin{array}{c}\text { short } \\
\text { gently } \\
\text { curved } \\
\text { ventrally }\end{array}$ & $\begin{array}{c}\text { short } \\
\text { gently } \\
\text { curved } \\
\text { ventrally }\end{array}$ & $\begin{array}{l}\text { long in } \\
\text { ventral } \\
\text { direction } \\
\text { strongly } \\
\text { curved }\end{array}$ & $\begin{array}{c}\text { long in } \\
\text { anterior } \\
\text { direction } \\
\text { hardly } \\
\text { curved }\end{array}$ & $\begin{array}{l}\text { short in } \\
\text { ventral } \\
\text { direction } \\
\text { strongly } \\
\text { curved } \\
\end{array}$ & $?$ & $?$ \\
\hline
\end{tabular}

toward dorsal valve, whereas the lateral commissure is slightly curved. Beak ridges rounded.

Interior of ventral valve. Hardly any development of secondary shell material in the apical region. Umbonal cavities free. Ventral median septum lacking. Dental plates thin and parallel to each other, leading into coarse and knob-like teeth that are pointing in a dorsal direction. Denticular cavities rounded in cross-section.

Interior of dorsal valve. Hardly any development of secondary shell material. Dorsal median septum short and thin. Septalium small and short, only developed in the posterior part of the shell with septalial plates that are oriented almost parallel to each other. Dental sockets rounded in cross-section. Inner socket ridges straight. Hinge plate very short, divided, and leading into short raduliform crura that do not extend far ventrally.
Stratigraphical and geographical occurrence. Callovian to Oxfordian (upper Middle to lower Upper Jurassic); Yemen, Jordan, Somalia.

Discussion. Daghanirhynchia susanae differs from $D$. macfadyeni in its smaller size, slightly greater development of secondary shell material, a subpentagonal outline, divergent dental plates, parallel septalial plates, and longer crura that are extending further in an anterior direction.

?Daghanirhynchia triangulata has 1 to 2 costae less on shells and on fold and sulcus and a narrower triangular outline than D. macfadyeni.

Daghanirhynchia angulocostata has two less costae than D. macfadeyni, a subpentagonal outline, and a longer dorsal median septum. 


\section{Daghanirhynchia angulocostata Cooper, 1989}

Fig. 6D

*v 1989 Daghanirhynchia angulocostata Cooper, p. 26-27, figs. 13, 14, pl. 6 figs. 1-19, pl. 7 figs. 44-53, pl. 11 figs. 16-21.

Holotype. Articulated specimens housed in the USNM under the repository number USNM 380201a; length $25.0 \mathrm{~mm}$, width $29.9 \mathrm{~mm}$, and thickness $19.6 \mathrm{~mm}$.

Type horizon and type locality. S1145, Hisyan Member, Upper Dhruma Formation, Callovian; Jebel Balaidiyah, in outlier at Khashm Balaidiyah, Saudi Arabia (detailed description is given in Cooper, 1989, appendix 2).
Material. 6 specimens. USNM 380201a, USNM 380201b, USNM 380404a, USNM 380441, USNM 380498a, USNM 380520.

Diagnosis. As in Cooper $(1989,26)$.

Description. Shells large, wide, and subpentagonal in outline with maximum width shifted toward the anterior margin. Anterior margin broadly rounded, uniplicate. Apical angle is 99 degrees. Fourteen to 16 costae on each shell, 3 to 5 on sulcus and 4 to 6 on fold. Sulcus starts slightly posterior to midvalve and widens rapidly. Sulcal tongue moderately long. Flanks bounding the sulcus narrow and become flat to slightly convex. Dorsal valve fairly strongly convex, median region swollen. Fold starting slightly posterior of midvalve elevating moderately, slowly

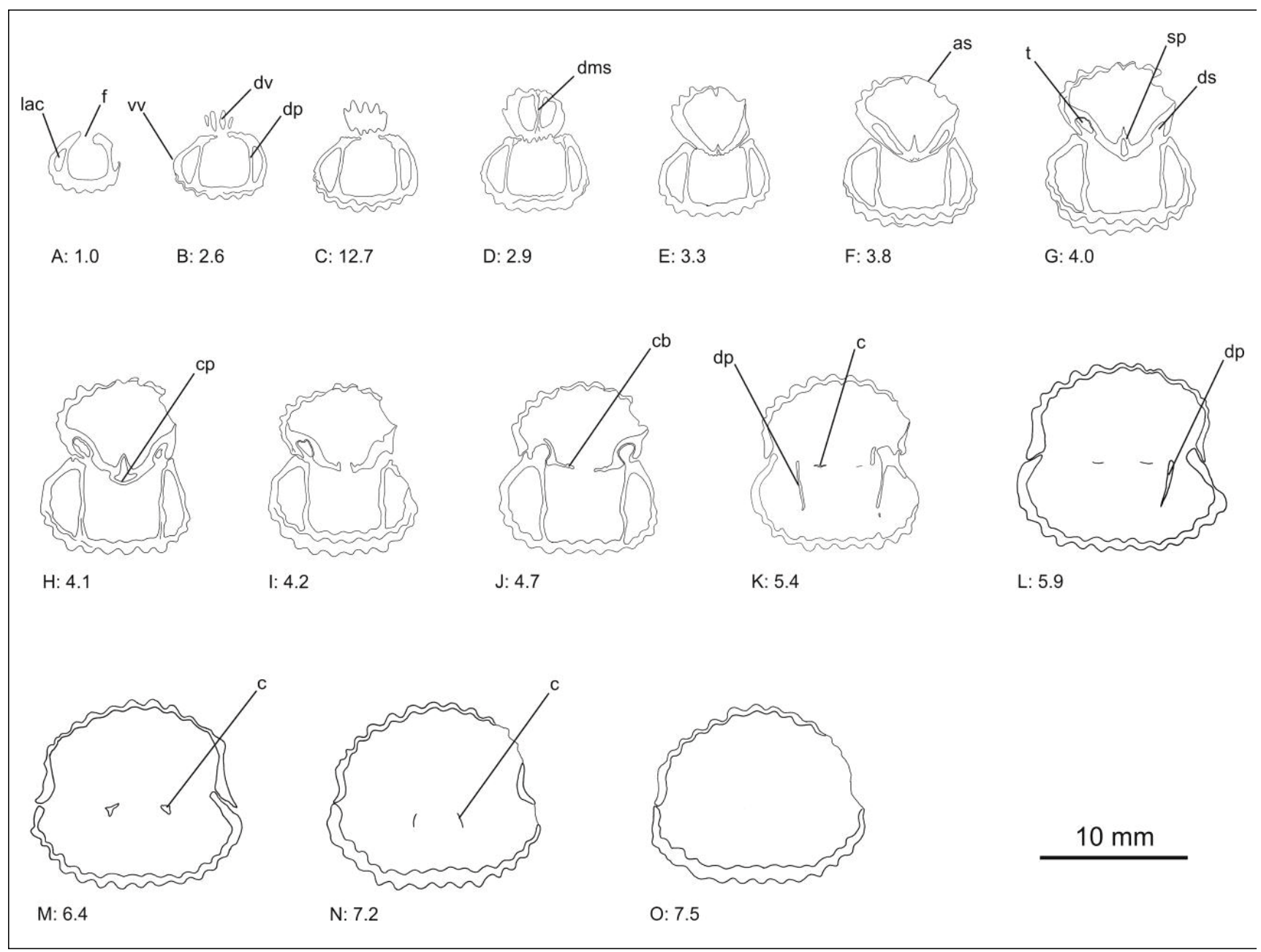

FIGURE 12 Drawings of grinding surfaces of serial sections perpendicular to commissural plane of articulated shell of Daghanirhynchia macfadyeni Muir-Wood, 1935 (unnumbered specimen). Numbers show section distance from apex in mm. Allfigures magnified (x2.0 ). As: abraded shell, c: crus, cb: crural base, dms: dorsal median septum, dp: dental plate, ds: dental socket, dv: dorsal valve, f: foramen, hp: hinge plate, s: septalium, t: tooth, vv: ventral valve, vuc: ventral umbonal cavity. 
widening at the anterior margin. Ventral beak narrow and suberect. Foramen large and elliptically elongated. Deltidial plates disjunct. Umbonal region slightly swollen.

\section{Interior of ventral valve. Unknown.}

Interior of dorsal valve. Septalium small. Dorsal median septum extends anteriorly about $1 / 3$ of valve length. The remaining features have not been studied due to the paucity of material.

Stratigraphical and geographical occurrence. Bajocian to Callovian (Middle Jurassic) Saudi Arabia, Tel el Dhahab section, Bed S-10, Mughanniyya Formation, (Callovian), Jordan.

Discussion. Daghanirhynchia angulocostata differs from $D$. susanae in that is has 1 to 2 more costae on fold and sulcus and larger shells.

?Daghanirhynchia triangulata has 1 to 3 less costae on fold and sulcus and a subtriangular outline, whereas $D$. angulocostata is subpentagonal. Figs. 5B, 6C

*v 2012b Daghanirhynchia susanae Feldman et al. p. 197-199, figs. 3C, 5.

Holotype. Articulated specimen housed at the AMNH under the repository number AMNH FI-72380; length $19.0 \mathrm{~mm}$, width $19.5 \mathrm{~mm}$, and thickness $15.4 \mathrm{~mm}$.

Type horizon and type locality. Bed S-7, Mughanniyya Formation, Callovian (upper Middle Jurassic), Wadi Zarqa, Arda Section, Jordan. (A detailed description is given in Feldman et al. (2012b) and herein.)

Material. 24 specimens. Tel el Dhahab section: AMNH FI-72380 (holotype), FI-72381- FI-72392 (bed s-7); GSI M731, GSI M 732, GSI M 741, GSI M 743, GSI M 4506, GSI M 4552, GSI M 4558 (all collected from the Tel el Dhahab section but beds not identified); Arda section: AMNH FI-72382, FI-72384, FI-72385, FI-72389.

Diagnosis. As in Feldman et al. (2012b, p. 198).

Description: Shells small to medium-sized, subpentagonal, dorsibiconvex with maximum width at about midlength. Apical angle is 96 degrees. Costae strong, angular, and coarse, numbering 12 to 16 on each shell, 2 to 3 in sulcus and 3 on fold. Fold and sulcus originating anterior to umbonal region of shell. Sulcus tongue high, mostly reaching to maximum curvature of dorsal valve, and with rounded to straight anterior margin. Ventral beak suberect to erect. Beak ridges rounded, strongly uniplicate anterior commissure, linguiform extension moderate, anterior margins end abruptly and a slightly stubby. Foramen small with disjunct deltidial plates.

Interior of ventral valve. Little development of secondary shell material, slightly filling the umbonal cavities. Ventral median septum lacking. Dental plates short and gently divergent leading into short and bulbous teeth that extend dorsally. Denticular cavities rounded and short.

Interior of dorsal valve. Little development of secondary shell material in apical region. Dorsal median septum short, but posteriorly imbedded into secondary shell material. Septalium imbedded or lacking, septalial plates parallel to each other. Dental sockets imbedded into secondary shell material. Hinge plates horizontal and thick. Crura slightly curved ventrally but extending far anteriorly.

Stratigraphical and geographical occurrence. Mughanniyya and Hamam formations, Bathonian to Callovian (Middle Jurassic), Jordan.

Discussion. Daghanirhynchia susanae differs from ?D. triangulata in its smaller shell size, a subpentagonal outline and 2 to 4 less costae on the shell.

\section{?Daghanirhynchia triangulata Cooper, 1989}

Fig. 6E

*v 1989 ?Daghanirhynchia triangulata Cooper, p. 2829, pl. 7 figs. 6-21, pl. 11 figs. 12-16.

v 2012 Daghanirhynchia? triangulata Feldman et al. p. 199-200, fig. 3E.

Holotype. Articulated shell housed at the USNM under the repository number USNM 380246; length $23.7 \mathrm{~mm}$, width $20.6 \mathrm{~mm}$, thickness $20.0 \mathrm{~mm}$. Remark: The shell is laterally broken, and width gives the measurement of the actual fossil specimen and not of the reconstructed original width.

Type horizon and type locality. S1444, Hisyan Member, Upper Dhruma Formation, Callovian; Dhruma quadrangle, Saudi Arabia (detailed description is given in Cooper, 1989, appendix 2).

Material. 4 specimens. USNM 380246 (holotype), USNM 380198, USMN 380250a, USNM 380380.

Diagnosis. As in Cooper (1989: 28).

Description. Triangular shells anteriorly rounded and narrow with maximum width located at the anterior 
margin. Gently dorsibiconvex. Apical angle is acute. Lateral commissure straight, anterior commissure strongly uniplicate. Ventral valve slightly swollen medially. Sixteen to 18 costae on each shell, 2 to 3 on sulcus, 3 to 4 costae on fold. Sulcus originating in umbonal region occupying nearly half the width, depressed below flanks throughout, strongly so on anterior half. Fold narrow, moderately elevated above flanks, and originating posterior to midvalve. Ventral beak fairly long and suberect. Foramen large. Deltidial plates narrow and disjunct.

Interior of ventral and dorsal valve. Unknown due to paucity of material.

Stratigraphical and geographical occurrence. Middle and Upper Dhruma Formation, Bathonian to Callovian (Middle Jurassic); Saudi Arabia, Jordan.

\section{CONCLUSIONS}

Owing to their strongly dorsibiconvex shells, outline, number of costae, and form of sulcus tongue, taxa of Daghanirhynchia are easy to recognize. The three-dimensional reconstructions of the internal shell morphology confirm the species assignments and diversity. The comparison of the Daghanirhynchia fauna from Jordan with the Daghanrhynchia fauna from different regions within the Ethiopian Province indicate that the maximum diversity of this genus occurs in the center of the Province (today's Jordan, Saudi Arabia, and Somalia).

\section{ACKNOWLEDGMENTS}

We thank Jann Thompson, Mark Florence, and Daniel Levin (National Museum of Natural History/Smithsonian Institution, Washington DC, USA) and Lee Davies and Martin Munt (Natural History Museum, London, UK) for providing access to the brachiopod collection and literature. Many thanks are due to Tina Emmel, Michael Ricker, and Erika Scheller-Wagner(all Senckenberg Forschungsinstitut and Naturmuseum, Frankfurt am Main, Germany) for technical help. H.R. F. would like to acknowledge the Touro College Faculty Research Fund for supporting this project and thank the members of its peer review panel. This research received support from the SYNTHESYS Project http://www.synthesys.info/, which is financed by European Community Research Infrastructure Action under the FP6 'Structuring the European Research Area' Programme (GB-TAF-5141) and (DE-TAF-1111). The visit of M. S.-G. to the American Museum of Natural History, New York, was supported by a Lerner Grey Award. M. S.-G. thanks Russell Garwood (Manchester University, UK) and Mark Sutton (Imperial College, London, UK) for instructions, help, and endless patience in solving SPIERS problems related to German and Portuguese computer systems.

\section{REFERENCES}

Ager, D.V., 1965. Mesozoic and Cenozoic Rhynchonellaceae. In: Moore, R.C. (ed.). Treatise on Invertebrate Paleontology. Brachiopoda. Lawrence, Kansas, Geological Society of America and University of Kansans, H597-H625.

Ahmad, F., 1998. Taxonomy and palaeoecology of the benthic macroinvertebrate fauna from the Middle Jurassic of northwestern Jordan. Doctoral thesis. Universität Würzburg, 200pp.

Ahmad, F., 2000. Middle Jurassic brachiopod faunas from northwestern Jordan. Neues Jahrbuch für Geologie und Paläontolgie, Monatshefte, 2000(5), 301-313.

Ahmad, F., 2002. On the Bajocian-Callovian macrofauna age of the Jurassic Rocks of Northwestern Jordan (Research Note). Dirasat, Pure Sciences, 29(1), 47-52.

Ahmad, F., 2003. Brachiopod faunas from the Middle Jurassic Mughanniyya Formation of Wadi Shaban, Jordan. Neues Jahrbuch für Geologie und Paläontolgie, Abhandlungen, 228(1), 37-59.

Bender, F. 1974. Geology of Jordan: Supplementary Edition in English with Minor Revisions. Berlin, Gebrueder Borntraeggger, 196pp.

Cooper, G.A., 1983. The Terebratulacea (Brachiopoda), Triassic to Recent: A study of the brachidia (Loops). Smithsonian Contributions to Paleobiology, 50, 1-290.

Cooper, G.A., 1989. Jurassic brachiopods of Saudi Arabia. Smithsonian Contributions to Paleobiology, 65, 1-213.

Dubar, G., 1967. Brachiopodes Jurassiques du Sahara Tunisien. Annales de Paleontologie, Invertebres, 53, 1-71.

Dúmeril, A.M.C., 1806. Zoologie analytique ou méthode naturelle de classification des nimaux. Paris, Allais, 344pp.

Feldman, H.R., 1986. Cladistic analysis of a Jurassic rhynchonellid brachiopod genus from the Middle Eastern Ethiopian Province. Kiamesha Lake (New York), Abstracts of the Geological Society of America Northeastern Section Meeting, 18, 16.

Feldman, H.R., 1987. A new species of the Jurassic (Callovian) brachiopod Septirhynchia from northern Sinai. Journal of Paleontology, 61, 1156-1172.

Feldman, H.R., Owen, E.F., Hirsch, F., 1991. Brachiopods from the Jurassic of Gebel El-Maghara, northern Sinai. American Museum Novitates, 3006, 1-28.

Feldman, H.R., Owen, E.F., Hirsch, F., 2001. Brachiopods from the Jurassic (Callovian) of Hamakhtesh Hagadol (Kurnub Anticline), southern Israel. Palaeontology, 44, 637-658.

Feldman, H.R., Schemm-Gregory, M., Garwood, R., Sutton, M.D., 2010. Digitized reconstruction of the internal hard-part anatomy of articulate brachiopods. Baltimore (Maryland), Geological Society of America, joint meeting, northeastern and southeastern, 42 (abstract), 63.

Feldman, H.R., Radulovic, V., Hegab, A.A.A., Radulovic, B., 2012a. Brachiopods from Gebel Engabashi, northern Sinai. Journal of Paleontology, 86, 238-252.

Feldman, H.R., Schemm-Gregory, M., Ahmad, F., Wilson, M.A., 
2012b. Rhynchonellid brachiopods from the Jordan Valley. Acta Palaeontolgica Polonica, 57, 191-204.

Ficcarelli, G., 1968. Fossili giuresi della serie sedimentaria del Nilo Azzurro meridionale. Rivista Italiana di Palaeontologia e Stratigrafia, 74, 23-50.

Hegab, A.A., 1989. New occurrence of Rhynchonellida (Brachiopoda) from the Middle Jurassic of Gebel El-Maghara, northern Sinai. Journal of African Earth Sciences, 9, 445-453.

Hegab, A.A., 1992. Terebratulida (Brachiopoda) from the Jurassic of Gebel El-Maghara, northern Sinai. Proceedings of the 8th Symposium of Phanerozoic Developments in Egypt, 8, 3342.

Howarth, M.K., Morris, N.J., 1998. The Jurassic and Lower Cretaceous of Wadi Hajar, southern Yemen. Bulletin of the Natural History Museum London, 54(1), 1-32.

Hudson, R.G.S., 1958. The Upper Jurassic faunas of southern Israel. Geological Magazine, 95(5), 415-425.

Jaboli, D., 1959. Fossili Giurassici dell'Harar (Africa Orientale): Brachiopodi, Lamellibranchi e Gasteropodi. Missione Geologica dell'Azienda Italiana Petroli (AGIP) nella Dancalia Meridionale e sugli Altipiani Hararini, 4(1), 3-100.

Khalil, B., Muneizel, S., 1992. Lithostratigraphy of the Jurassic outcrops of North Jordan (Azab Group). Natural Resources Authority of Jordan. Geological Mapping Division, Bulletin, 21, 1-50.

Kiessling, W., Kumar Pandey, D., Schemm-Gregory, M., Mewis, H., Aberhan, M., 2011. Marine benthic invertebrates from the Upper Jurassic of northern Ethiopia and their biogeographical affinities. Journal of Asian Earth Sciences, 59, 195-214. DOI: 10.1016/j.jafrearsci.2010.10.006

Krawczynski, C., Wilson, M.A., 2011. The first Jurassic thecideide brachiopods from the Middle East: Anew species of Moorellina from the Upper Callovian of Hamakhtesh Hagadol, southern Israel. Acta Geologica Polonica, 61, 71-77.

Kuhn, O. 1949. Lehrbuch der Paläozoologie. Stuttgart, Schweizerbart'sche Verlagsbuchhandlung, 326pp.

Libbey, W., Hoskins, F.E., 1905. The Jordan Valley and Petra. New York, G.P. Putnam's Sons, 353pp.

Manceñido, M.O., Owen, E.I., Sun Dongli, Dagys, A.S., 2002. Hemithiridoidea. In: Kaesler, R.L. (ed.). Treatise on Invertebrate Paleontology. Part $\mathrm{H}$, Brachiopoda, revised. Boulder, Colorado and Lawrence, Kansas, Geological Society of America and University of Kansans, 1326-1369.

Muir-Wood, H.M., 1935. Jurassic Brachiopoda. In: MacFayden, W.A. (ed.). The Mesozoic Palaeontology of British Somaliland. Geology and Palaeontology of British Somaliland, II. London, Government of Somaliland Protectorate, 75-147.

Muir-Muir-Wood, H.M., 1937. The Mesozoic Brachiopoda of the Attock District. Memoirs of the Geological Survey of India,
Palaeontologia Indica, 20(6), 1-34.

Rousselle, L., 1965. Rhynchonellidae, Terebratulidae, et Zeilleridae du Dogger Marocain (Moyen-Atlas Septentrional, Hauts Plateaux, Haut Atlas). Notes et Memoires du service des Mines et de la Carte Géologique du Maroc, 187, 1-168.

Rzhonsnitskaya, M.A., 1956. Systematization of Rhynchonellida. In: Guzman, E., Ayala-Castanares, A. (eds.). Resúmenes de los Trabajos Presentados. México, International Geological Congress, 20 (Report), 125-126.

Sharief, F., Khan, A., Mohammed, S., Kinji, M., 1991. Outcropsubcrop sequence and diagenesis of Upper Jurassic Arab-Hith Formations, central Saudi Arabia. Journal of King Abdulazziz University (KAU) Earth Sciences, 4, 105-136.

Shi Xiaoying, Grant, R.E., 1993. Jurassic rhynchonellids: internal structures and taxonomic revisions. Smithsonian Contributions to Paleobiology, 73, 1-190.

Stefanini, G., 1925. Description of fossils from south Arabia and British Somaliland. In: Little, O.H. (ed.). The Geography and Geology of Makalla (South Arabia). Cairo, Geological Survey of Egypt, 143-250.

Sutton, M.D, Briggs, D.E.G., Siveter, D.J., Siveter, D.J., 2001. Methodologies for the visualization and reconstruction of three-dimensional fossils from the Silurian Herefordshire Lagerstätte. Paleontologia Electronica, 4(1), article 2, 1-17. Website: http://palaeo-electronica.org/2001_1/s2/issue1_01. htm

Sutton, M.D, Briggs, D.E.G., Siveter, D.J., Siveter, D.J., 2005. Silurian brachiopods with soft-tissue preservation. Nature, 436, 1013-1015.

Weir, J., 1925. Brachiopoda, Lamellibranchiata, Gastropoda and belemnites in the collection of fossils and rocks from Somaliland made by Mssr B.K.N. Wyllie and W.R. Smellie. Glasgow University, Monographs of the Geological Department of the Hunterian Museum, 3, 1-63.

Weir, J., 1929. Jurassic fossils from Jubaland, East Africa, collected by G.V. Glenday, and the Jurassic Geology of Somaliland by Mssr B.K.N. Wyllie and W.R. Smellie. Monographs of the Geological Department of the Hunterian Museum, 1, 79-110.

Wetzstein, A., 1859. Reise in die beiden Trachonen und um das Haurän-Gebirge. Zeitschrift für Allgemeine Erdkunde, Neue Folge, 7, 109-208.

Williams, A., Carlson, S.J., Brunton, C.H.C., Holmer, L.E., Popov, L.E., 1996. A supra- ordinal classification of the Brachiopoda. Philosophical Transaction of the Royal Society of London, series B, 351, 1171-1193.

Wood, H.M., 1936. A monograph on the Brachiopoda of the British Great Oolite Series. I: The Brachiopoda of the Fuller's Earth. Paleontographical Society, 89(1), 1-144.

Manuscript received February 2013;

revision accepted September 2013; published Online November 2013. 